\title{
New Type III Effectors \\ from Xanthomonas campestris pv. vesicatoria Trigger Plant Reactions Dependent on a Conserved N-Myristoylation Motif
}

\author{
Frank Thieme, ${ }^{1}$ Robert Szczesny, ${ }^{1}$ Alexander Urban, ${ }^{1}$ Oliver Kirchner, ${ }^{1}$ Gerd Hause, ${ }^{2}$ and Ulla Bonas ${ }^{1}$ \\ ${ }^{1}$ Institut für Biologie, Bereich Genetik, Martin-Luther-Universität Halle-Wittenberg, D-06099 Halle/Saale, Germany; \\ ${ }^{2}$ Biozentrum der Martin-Luther-Universität Halle-Wittenberg, D-06099 Halle/Saale, Germany
}

Submitted 4 April 2007. Accepted 20 May 2007.

\begin{abstract}
Pathogenicity of the gram-negative plant pathogen Xanthomonas campestris pv. vesicatoria depends on a type III secretion system, which translocates bacterial effector proteins into the plant cell. In this study, we identified two novel type III effectors, XopE1 and XopE2 (Xanthomonas outer proteins), using the AvrBs3 effector domain as reporter. XopE1 and XopE2 belong to the HopX family and possess a conserved putative $\mathrm{N}$-myristoylation motif that is also present in the effector XopJ from $X$. campestris pv. vesicatoria 85-10. XopJ is a member of the YopJ/AvrRxv family of acetyltransferases. Confocal laser scanning microscopy and immunocytochemistry revealed that green fluorescent protein fusions of XopE1, XopE2, and XopJ localized to the plant cell plasma membrane. Targeting to the membrane is probably due to $\mathrm{N}$-myristoylation, because a point mutation in the putative myristoylated glycine residue G2 in XopE1, XopE2, and XopJ resulted in cytoplasmic localization of the mutant proteins. Results of hydroxylamine treatments of XopE2 protein extracts suggest that the proteins are additionally anchored in the host cell plasma membrane by palmitoylation. The membrane localization of the effectors strongly influences the phenotypes they trigger in the plant. Agrobacteriummediated expression of xopE1 and xopJ in Nicotiana benthamiana led to cell-death reactions that, for xopJ, were dependent on the $\mathrm{N}$-myristoylation motif. In the case of $x o p E 1(G 2 A)$, cell death was more pronounced with the mutant than with the wild-type protein. In addition, XopE2 has an avirulence activity in Solanum pseudocapsicum.
\end{abstract}

Additional keyword: bacterial spot disease, pepper, tomato.

Corresponding author: U. Bonas; E-mail: ulla.bonas@genetik.unihalle.de; Telehone: (+49) 345 5526290; Fax: (+49) 3455527277.

Current address for A. Urban: Institut für Biochemie und Biologie, Universität Potsdam, D-14476 Golm, Germany.

Current address for O. Kirchner: Schott Jenaer Glas GmbH, 07745 Jena, Germany.

Nucleotide sequence data for Xanthomonas campestris pv. vesicatoria 85-10 effectors XopE1, XopE2, and XopJ are available in the GenBank database under accession numbers CAJ21925, CAJ23957, and CAJ23833, respectively.
Plants have evolved effective strategies to recognize possible pathogens and trigger defense reactions against the invader (Nürnberger et al. 2004; Schornack et al. 2006). On the other hand, bacterial plant pathogens employ sophisticated mechanisms to conquer their hosts, i.e., they suppress basic plant defense reactions. Pathogenicity of most gram-negative, bacterial pathogens depends on a highly conserved type III secretion (T3S) system (Büttner and Bonas 2006). The T3S system translocates a large number of type III effector proteins directly into the host cell cytosol. Bacterial mutants in which type III translocation is abolished are nonpathogenic, indicating that the successful interaction with the host depends on effector protein translocation (Alfano and Collmer 2004). Many type III effectors were first identified as products of avirulence (avr) genes, which are specifically recognized in a resistant plant that expresses the corresponding resistance gene. Recognition most often results in the induction of the hypersensitive response (HR), a rapid, localized programmed cell-death reaction of the infected tissue that ultimately arrests bacterial growth (Klement 1982; Staskawicz 2001). However, it is now clear that the primary function of many Avr and other effector proteins is in the establishment of the infection, i.e., in virulence (Grant et al. 2006; Mudgett 2005). More recently, effector genes have been discovered by transposonbased screens using reporter-gene fusions (Guttman et al. 2002; Roden et al. 2004b), their coregulation with the T3S system, and bioinformatic approaches (Chang et al. 2005; Fouts et al. 2002; Noël et al. 2001, 2002, 2003; Schechter et al. 2006).

An important question concerns the localization and molecular function a given effector protein displays inside the plant cell. Several effectors have an enzymatic function (Grant et al. 2006; Mudgett 2005), e.g., AvrPtoB from Pseudomonas syringae, an E3-ubiquitin ligase with plant cell death suppressing activity (Abramovitch et al. 2006; Janjusevic et al. 2006). Another example is XopD (Xanthomonas outer protein D) from Xanthomonas campestris pv. vesicatoria, which belongs to the C48-family of SUMO (small ubiquitin-like modifier) cysteine proteases and localizes to the plant cell nucleus (Hotson et al. 2003). A number of type III effector proteins show a distinct subcellular localization in the plant cell, e.g., targeting to the plasma membrane. Examples are the Pseudomonas effectors AvrB, AvrRpm1, AvrPphB, AvrPto, and HopF2, the membrane localization of which depends on $\mathrm{N}$-myristoylation motifs that mediate fatty acid modification of the effector in the eukaryotic cell (Nimchuk et al. 2000; Robert-Seilaniantz et al. 2006; Shan 
et al. 2000). Interestingly, the N-myristoylation motif of these effectors is required for their avirulence and virulence function (Nimchuk et al. 2000; Robert-Seilaniantz et al. 2006; Shan et al. 2000).

Our laboratory studies the T3S system and type III effector proteins from Xanthomonas campestris pv. vesicatoria (also designated Xanthomonas axonopodis pv. vesicatoria [Vauterin et al. 2000] or Xanthomonas euvesicatoria [Jones et al. 2004]), the causal agent of bacterial spot disease in pepper and tomato (Gürlebeck et al. 2006). The T3S system of X. campestris pv. vesicatoria is encoded by the $23-\mathrm{kb}$ chromosomal hrp (hypersensitive response and pathogenicity) gene cluster (Gürlebeck et al. 2006). hrp mutants are unable to grow and to cause disease symptoms in susceptible plants or to induce the HR in resistant host and nonhost plants (Bonas et al. 1991). Expression of hrp and most effector genes is induced in planta (Noël et al. 2001, 2002, 2003; Schulte and Bonas 1992). Key regulators are the OmpR-family regulator $\mathrm{HrpG}$ and $\mathrm{HrpX}$, an AraC-type transcriptional activator whose expression is induced by $\mathrm{HrpG}$ (Wengelnik and Bonas 1996; Wengelnik et al. 1996). HrpX binds to the cis-regulatory PIP (plant-inducible promoter) box in the promoter region of regulated genes (Koebnik et al. 2006).

Up to now, 15 type III effector proteins have been confirmed experimentally in $X$. campestris pv. vesicatoria 85-10 or closely related strains (Gürlebeck et al. 2006). Recently, the genome sequence of $X$. campestris pv. vesicatoria 85-10 (Thieme et al. 2005) was exploited to identify new type III effector candidates. In this study, we present two new Xanthomonas type III effector proteins, XopE1 and XopE2, which possess putative $\mathrm{N}$-myristoylation motifs in their $\mathrm{N}$ termini. Such a motif is also present in the effector XopJ, which we described previously (Noël et al. 2003). Subcellular localization studies of XopE1, XopE2, XopJ, and mutant versions thereof, using fusions to the green fluorescent protein (GFP), showed localization to the plant cell plasma membrane that is dependent on the N-myristoylation motif. The motif was also important for the induction of cell-death reactions in Nicotiana species triggered by XopE1 and XopJ. For XopE2 an avirulence activity in Solanum pseudocapsicum was uncovered that was independent of the N-myristoylation motif.

\section{RESULTS}

\section{Identification and verification}

of the new type III effectors XopE1 and XopE2.

Homology searches of the genomic sequence of $X$. campestris pv. vesicatoria 85-10 (Thieme et al. 2005) identified new putative type III effector genes. Here, we describe the chromosomal genes xopE1 (XCV0294) and xopE2 (XCV2280), which are highly identical to each other (79\% DNA sequence identity). The predicted proteins XopE1 and XopE2 share 69\% aminoacid sequence identity and belong to the HopX2 subgroup of the HopX family of type III effector proteins (63 and 79\%, respectively, amino-acid sequence identity to HopX2 from $P$. syringae pv. maculicola) (Guttman et al. 2002; Lindeberg et al. 2005; Rohmer et al. 2004). The HopX family includes homologs of AvrPphE (HopX1 subgroup) and HopPmaB (HopX2 subgroup) from $P$. syringae, Ralstonia solanacearum, and Xanthomonas spp. (Lindeberg et al. 2005; Rohmer et al. 2004). All proteins of the HopX2 subgroup possess a putative N-myristoylation motif, which has not yet been studied (discussed below) (Table 1).

To investigate whether XopE1 and XopE2 are indeed type III effectors, we tested for their secretion in vitro and translocation into the plant cell. For this, we generated translational fusions with the reporter protein AvrBs3 $\Delta 2$, which lacks a T3S and translocation signal (Noël et al. 2003; Szurek et al. 2002). Fusion of a functional $\mathrm{T} 3 \mathrm{~S}$ and translocation signal to AvrBs $3 \Delta 2$ leads to its translocation and thus the induction of the HR in Early Cal Wonder (ECW)-30R pepper plants, which harbor the corresponding resistance gene $B s 3$ (Noël et al. 2003). The promoter and 5 ' coding regions of $x o p E 1$ and $x o p E 2$, respectively, were fused to avrBs3 42 in pL6GW356 (Noël et al. 2003). As controls, we used AvrBs3 22 (Szurek et al. 2002), AvrBs3 $3_{1-200}$-AvrBs3 32 (Noël et al. 2003), and HrpF $387-$ AvrBs3 $\Delta 2$, which is secreted but not translocated (Büttner et al. 2002). The fusion constructs were conjugated into $X$. campestris pv. vesicatoria strains $85^{*}$ (Wengelnik et al. 1999), the T3S mutant $85^{*} \Delta h r c V$, which is deleted in a gene coding for a conserved inner membrane component of the T3S system (Rossier et al. 2000), and $85^{*} \Delta h r p F$, which is T3S-competent but translocation deficient (Büttner et al. 2002). Strain $85^{*}$ is a

Table 1. Conserved N-termini of effector proteins from Xanthomonas and Pseudomonas spp. harbor putative N-myristoylation signals

\begin{tabular}{|c|c|c|c|c|}
\hline Organisma $^{a}$ & Effector protein ${ }^{b}$ & Accession number & $\mathrm{N}$-terminal amino-acid sequence ${ }^{\mathrm{c}}$ & Putative function or family membership \\
\hline \multirow[t]{3}{*}{$X c v 85-10$} & XopE $1^{d}$ & CAJ21925 & MGLCISKPAM SGSSVAASPE & HopX2 family \\
\hline & XopE2 ${ }^{\text {d }}$ & CAJ23957 & MGL CSSKPSV VGSPVAGSPE & HopX2 family \\
\hline & $\mathrm{XopJ}^{\mathrm{d}}$ & AAK72486 & MGLCVSKPSV AGSPEHYAAH & acetyltransferase \\
\hline \multirow[t]{3}{*}{ Хac 306} & AvrXacE1 & AAM35178 & MGLCVSRPA T SGSSVAASPE & HopX2 family \\
\hline & AvrXacE3* & AAM39257 & MGLCSSIKPSV AGSPVAGSPE & HopX2 family \\
\hline & XAC3230 & AAM38074 & MGL TSKPSV VGSPVAGSPE & ADP-ribosyl transferase \\
\hline$X c c$ & AvrXccB* & AAM42989 & MGL CNSKSVA GSVVGSPIAT & Acetyltransferase \\
\hline \multirow[t]{2}{*}{ ATCC33913 } & AvrXccC* & AAM41397 & MGL ASKPSV AGSPARYTTH & AvrB1 homolog \\
\hline & AvrXccE1 & AAM40923 & MGLCVSKPSV AGSPDHYATH & HopX2 family \\
\hline \multirow[t]{3}{*}{ Xcc 8004} & XC_2004* & AAY49067 & MGLCASKPSV AGSPARYTTH & AvrB1 homolog \\
\hline & $\mathrm{XC} \_2602$ & AAY49651 & MGL C VSKPSV AGSPDHYATH & HopX2 family \\
\hline & XC_3802* & AAY50842 & MGL NSKSVA GSVVGSPIAT & Acetyltransferase \\
\hline \multirow[t]{2}{*}{ P. syringae } & HopX2d & AAL84240 & MGL CVSKGST ASSPQHYAVR & HopX2 family \\
\hline & HopZ2 $^{\text {d }}$ & CAC 16700 & MGICVSIKPSV RHDYNEDYGR & Acetyltransferase \\
\hline
\end{tabular}

${ }^{\mathrm{a}}$ X. campestris pv. vesicatoria 85-10 (Xcv 85-10), X. axonopodis pv. citri 306 (Xac 306), X. campestris pv. campestris ATCC33913 and 8004 (Xcc ATCC33913, Xcc 8004), P. syringae pv. maculicola (HopX2) and P. syringae pv. pisi (HopZ2).

${ }^{\mathrm{b}}$ For Pseudomonas effectors the unified nomenclature was used (Lindeberg et al. 2005). Asterisks indicate a manual change of the predicted translational start position (GLIMMER-based gene prediction leads to approximately 40\% wrongly assigned start codons [Zhu et al. 2004]). The here-predicted start codon for $a v r X c c C$ was recently verified experimentally (Castañeda et al. 2005).

${ }^{\mathrm{c}}$ Characteristic features of the N-myristoylation signal. The putatively myristoylated glycine residue is labeled in black. Residues likely to interact with the active center of the eukaryotic N-myristoyl transferase are shaded in light gray. The conserved cysteine residue (white) might be palmitoylated. Residues that might interact with the surface of the N-myristoyl transferase are shaded in dark gray. The less well-conserved hydrophilic linkers are boxed.

${ }^{\mathrm{d}}$ Experimentally verified type III effectors: XopE1 and XopE2 (this study); XopJ (Noël et al. 2003); HopX2 (Guttman et al. 2002); HopZ2 (Arnold et al. 2001). 
A

$\frac{\begin{array}{c}\text { Total } \\ \text { extracts }\end{array}}{8^{85^{*}} \begin{array}{l}85^{\star} \quad 85^{\star} \\ \Delta h r c V \Delta h r p F\end{array}} \frac{\begin{array}{c}\text { Culture } \\ \text { supernatants }\end{array}}{85^{*} \begin{array}{c}85^{\star} \quad 85^{\star} \\ \Delta h r c V \Delta h r p F\end{array}}$

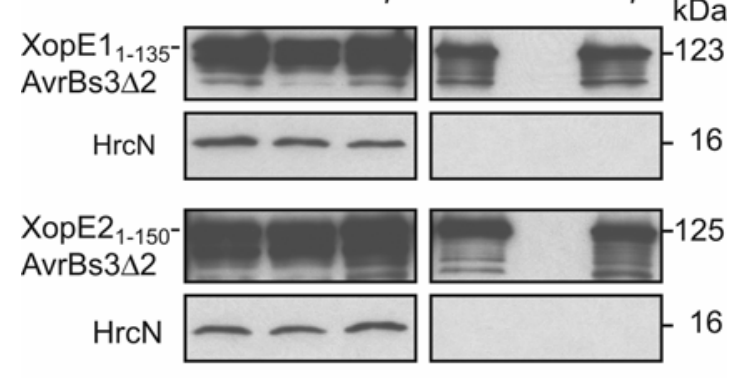

B

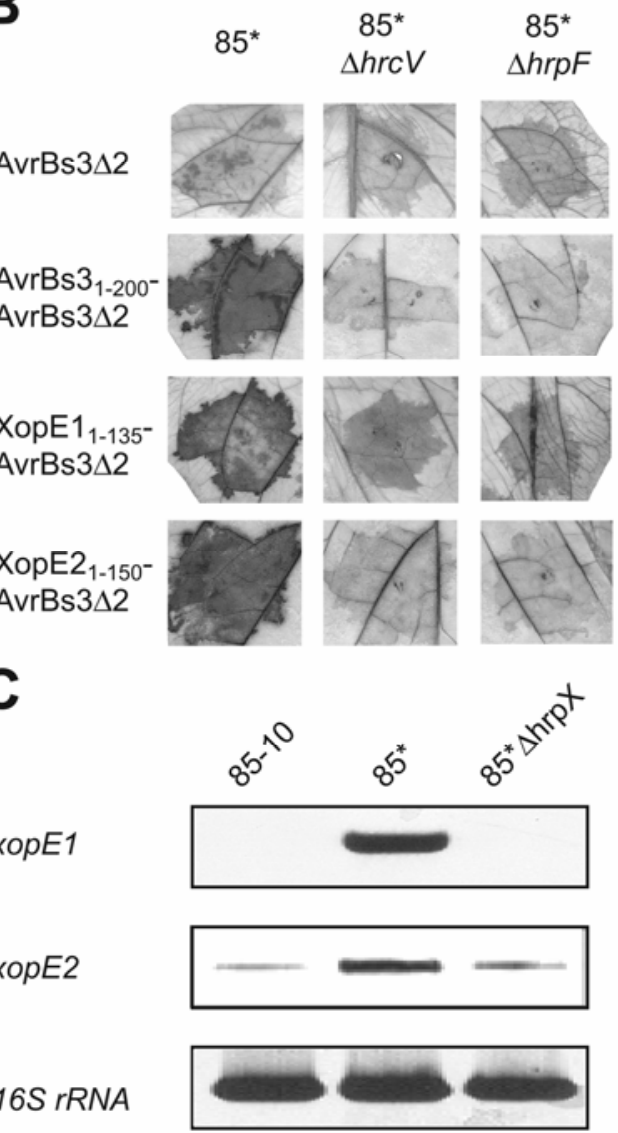

Fig. 1. The $\mathrm{N}$ termini of XopE1 and XopE2 harbor type III secretion signals and target the reporter AvrBs $3 \Delta 2$ into the plant cell. A, In vitro secretion assay of Xop-AvrBs $3 \Delta 2$ fusion proteins. X. campestris pv. vesicatoria strains $85^{*}$, the T3S-deficient mutant $85^{*} \Delta h r c V$, and the translocation-deficient mutant $85^{*} \Delta h r p F$ expressing the AvrBs $3 \Delta 2$ chimeras as indicated were incubated in secretion medium. Equal protein amounts of total extracts and supernatants were analyzed by immunoblotting, using an AvrBs3-specific antibody. Membranes were reprobed with a specific antibody against the intracellular protein $\mathrm{HrcN}$ to ensure that no bacterial lysis had occurred. B, In vivo translocation assay. $X$. campestris pv. vesicatoria strains $85^{*}, 85^{*} \Delta h r c V$, and $85^{*} \Delta h r p F$ expressing the AvrBs $3 \Delta 2$ fusion constructs as indicated were infiltrated into AvrBs3responsive ECW-30R plants. Leaves were harvested two days postinoculation and bleached in ethanol for better visualization of the hypersensitive response. C, xopE1 and xopE2 belong to the Hrp regulon. Reverse transcription-polymerase chain reaction analysis of the type III effector genes xopE1 and xopE2. X. campestris pv. vesicatoria strains 85-10, 85*, and $85^{*} \Delta h r p X$ were grown in NYG medium (Daniels et al. 1984). 16S rRNA was used as constitutive control. The DNA samples were separated on a $1.5 \%$ agarose gel and were stained with ethidium bromide. The results of one representative experiment are shown. derivative of strain $85-10$ and carries a point mutation in the regulatory gene $h r p G$ leading to constitutive expression of the T3S system (Wengelnik et al. 1999). Expression of the fusion proteins in Xanthomonas was verified by Western blot analysis, using an AvrBs3-specific antibody (Fig. 1A). When the bacteria were incubated in secretion medium, XopE1 $1_{1-135}$ and XopE2 $2_{1}$ $150^{-A v r B s} 3 \Delta 2$ were detected in the culture supernatants of strain $85^{*}$ and $85^{*} \Delta h r p F$ but not of $85^{*} \Delta h r c V$ (Fig. 1A). To ensure that no bacterial lysis had occurred, the blots were reprobed with an antibody against $\mathrm{HrcN}$, an intracellular component of the T3S system (Rossier et al. 2000) (Fig. 1A). These results demonstrate that XopE1 and XopE2 contain functional T3S signals in their N-terminal regions.

To test for type III-dependent translocation, strains $85^{*}$, $85^{*} \Delta h r c V$, and $85^{*} \Delta h r p F$ expressing AvrBs $3 \Delta 2$ and the fusion constructs described above, respectively, were inoculated into leaves of ECW-30R plants and the near-isogenic susceptible pepper line ECW that lacks the $B s 3$ resistance gene. Strain $85^{*}$ derivatives expressing AvrBs3 ${ }_{1-200^{-}}$AvrBs3 32 , XopE1 1-135AvrBs $3 \Delta 2$, and XopE2 ${ }_{1-150}-$ AvrBs $3 \Delta 2$ fusions, respectively, induced the HR in ECW-30R (Fig. 1B) but not in ECW plants (data not shown). As expected, no HR induction was observed in plants infected with strain $85^{*}$ expressing AvrBs3 $\Delta 2$ (Fig.

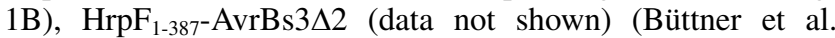
2002), and strains $85^{*} \Delta h r c V$ and $85^{*} \Delta h r p F$ expressing the chimeric proteins (Fig. 1B). Taken together, the type III-dependent translocation demonstrates that XopE1 and XopE2 are indeed effector proteins.

\section{xopE1 and xopE2 are members of the HrpG regulon.}

To analyze the regulation of expression of the new effector genes, we performed reverse transcription-polymerase chain reaction (RT-PCR) analyses of the $X$. campestris pv. vesicatoria wild-type strain $85-10$, its derivative $85^{*}$, and the $h r p X$ deletion mutant $85^{*} \Delta h r p X$ (Noël et al. 2001) grown in complex NYG medium (Daniels et al. 1984). As shown in Figure $1 \mathrm{C}$, transcripts of $x o p E 1$ and $x o p E 2$ are highly abundant in strain $85^{*}$ but not $(x o p E 1)$ or in much lower amounts (xopE2) in strains 85-10 and $85^{*} \Delta h r p X$. This indicates that $x o p E l$ and xopE2 are HrpG- and HrpX-dependently expressed and, thus, coregulated with the T3S system.

\section{XopE1, XopE2, and XopJ harbor a conserved $\mathrm{N}$-myristoylation motif and localize to the plant cell plasma membrane.}

Inspection of the XopE1 and XopE2 amino-acid sequences revealed a putative $\mathrm{N}$-myristoylation motif in both $\mathrm{N}$-termini. These typical eukaryotic motifs suggest that XopE1 and XopE2 might be acylated in the host cell cytosol and targeted to the plasma membrane (Farazi et al. 2001) (Table 1). The Nmyristoylation motif is conserved in other effectors from Xanthomonas and Pseudomonas spp. (Table 1) and suggests myristoylation of the N-terminal glycine residue (G2) in planta. Additionally, the conserved cysteine residue at position 4 could be palmitoylated (Linder and Deschenes 2007) (Table 1). XopE1, XopE2, and the effector XopJ (Noël et al. 2003) are the only proteins of $X$. campestris pv. vesicatoria 85-10 that possess this motif.

To investigate the subcellular localization of XopE1, XopE2, and XopJ, we used GFP as reporter. The three genes were translationally fused to $g f p$ in a binary vector under control of the Cauliflower mosaic virus $35 \mathrm{~S}$ promoter and transiently expressed in leaves of the solanaceous plant Nicotiana benthamiana, using Agrobacterium-mediated gene transfer. Immunoblot analysis of XopE1 and XopJ fusion proteins $30 \mathrm{~h}$ postinoculation (hpi) and of XopE2 fusions 48 hpi showed stable expression (Fig. 2A). Subcellular localization of the GFP 
fusion proteins was determined by confocal laser scanning microscopy of lower epidermal cells. The GFP control was clearly detectable in the cytoplasm surrounding chloroplasts and nuclei, in the nuclei, and in cytoplasmic strands spanning the tonoplast (Fig. 3A and B). Nuclei were visualized by DAPI (4',6-diamidino-2-phenylindole) staining. In contrast to GFP, the fluorescence of the XopE1::GFP, XopE2::GFP, and XopJ::GFP fusions was clearly confined to the periphery of the cells and was not detectable in the nucleus or in the cytoplasm (Fig. 3A and B).

Localization of the XopE2::GFP and XopJ::GFP fusion proteins to the plasma membrane of $N$. benthamiana mesophyll cells could be confirmed by immunocytochemistry. XopE1 was not studied because of its low expression. Leaf sections of Agrobacterium-infected $N$. benthamiana were analyzed $30 \mathrm{hpi}$ by immunofluorescence, using anti-GFP and fluorescent Alexa 488 antibodies. As shown in Figure 4A, XopE2::GFP and XopJ::GFP were only detected in the periphery of the mesophyll cells and not in the cytoplasm surrounding the chloroplasts or the DAPI-stained nucleus. Untreated leaf material and GFP were used as negative controls (Fig. 4A). Bright green fluorescence of immunolabeled GFP was detectable in the cytoplasm surrounding the chloroplasts and in the nucleus, as expected (Fig. 4A).

To confirm the localization on the ultrastructural level we carried out electron microscopy of $N$. benthamiana leaf tissue expressing XopJ::GFP. The protein was detected by immunolabeling with anti-GFP and gold particle-conjugated antibodies and showed a predominant localization to the plasma membrane (Fig. 4B).

Localization and modification of XopE1, XopE2, and XopJ in the plant cell depends on the $\mathbf{N}$-terminal glycine residue.

To test whether the membrane localization of XopE1, XopE2, and XopJ is due to myristoylation, the glycine residue at amino-acid position 2 of each protein was substituted by alanine or glutamic acid, using site-directed mutagenesis. The mutant fusion proteins XopE1(G2A)::GFP, XopE2(G2A)::GFP, XopE2(G2E)::GFP, and $\mathrm{XopJ}(\mathrm{G} 2 \mathrm{E}):: \mathrm{GFP}$ in $N$. benthamiana clearly localized to the cytoplasm, similarly to the GFP control (Fig. 3A; data not shown). Immunocytochemistry of mesophyll cells confirmed these results. XopE2(G2E)::GFP and XopJ(G2E)::GFP were detected in the cytoplasm and nucleus (Fig. 4A). The cytoplasmic localization of the XopJ(G2E)::GFP fusion protein was confirmed by electron microscopy (Fig. 4B).

Immunoblot analyses demonstrated that the fusion proteins had the expected molecular mass, indicating that the difference in localization was not due to protein instability (Fig. 2A; data not shown). Thus, the glycine residue at amino-acid position 2 of XopE1, XopE2, and XopJ is essential for localization to the plant cell plasma membrane.

Close inspection of the immunoblot in Figure 2A revealed a higher molecular mass of XopE2::GFP and XopJ::GFP compared with the respective myristoylation motif mutants. For XopE1, a size difference was barely detectable (Fig. 2A). Together with the localization studies (Figs. 3 and 4), these data strongly suggest that the wild-type XopE1, XopE2, and XopJ proteins are modified in planta. We reasoned that the posttranslational modification could be covalent linkage of acyl chains subsequent to myristoylation, e.g., palmitoylation via thioester bonds (Linder and Deschenes 2007). To examine this possibility, protein extracts from $N$. benthamiana leaves expressing XopE2::GFP and XopE2(G2A)::GFP were treated with hydroxylamine to release thioester bonds (Linder and Deschenes 2007). Immunoblot analyses revealed two distinct signals that correspond in size to the untreated control ("Tris") and the XopE2(G2A)::GFP mutant version (Fig. 2B). These findings strongly suggest that XopE2 is modified in the plant cell by myristoylation and subsequent palmitoylation.

\section{XopE1, XopE2, and XopJ trigger cell death in different Solanaceae spp.}

To study the contribution of xopE1 and xopE2 to bacterial virulence, nonpolar deletions of both genes were generated in $X$. campestris pv. vesicatoria 85-10. A xopJ mutant has been described earlier (Noël et al. 2003). The single and double xopE1 and xopE2 mutants were tested for symptom formation and growth in susceptible pepper plants (ECW) and for the HR elicitation in resistant pepper plants (ECW-10R). Strain 85-10 expresses the avirulence protein AvrBs1, which is recognized in ECW-10R, which harbors the Bsl resistance gene (Minsavage et al. 1990). Bacterial strains carrying single or double deletions in xopE1 and xopE2 showed no significant difference in disease symptoms and the HR induction when compared with wild-type strain 85-10, even at low inoculation densities (data not shown). Furthermore, growth of single xopE1 and xopE2 mutants and the double mutant in susceptible pepper plants was not significantly altered (Fig. 5). Similar results were obtained previously for a xopJ mutant (Noël et al. 2003).

Because no obvious virulence or avirulence activities were identified for XopE1, XopE2, and XopJ in the host plant Capsicum annuum, we inoculated 17 different solanaceous species with Xanthomonas wild-type and xopE1/xopE2 double mutant strains and with Agrobacterium strains mediating the expression of xopE1, xopE2, xopJ, and $g f p$, respectively. Differential

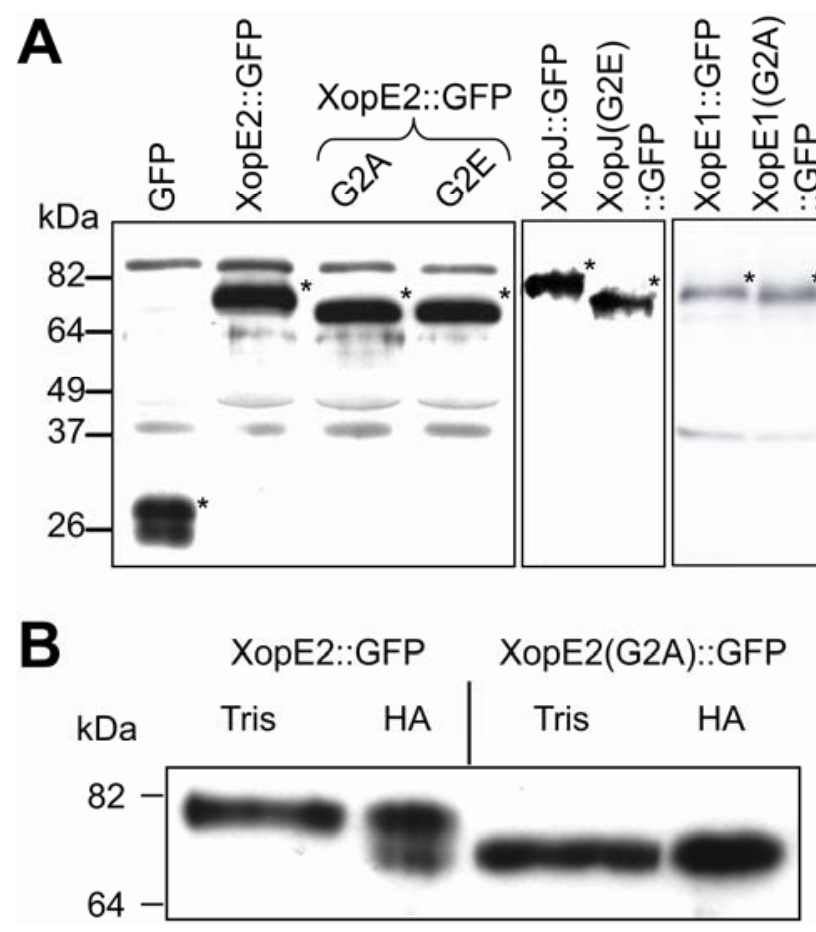

Fig. 2. In planta expression of wild-type and mutant Xop::GFP fusions. A, XopE1::GFP, XopE2::GFP, and XopJ::GFP fusion proteins are stably expressed in planta. Agrobacterium strains that mediate T-DNA-based delivery of $x o p E 1:: g f p, x o p E 1(\mathrm{G} 2 \mathrm{~A}):: g f p, x o p E 2:: g f p, x o p E 2(\mathrm{G} 2 \mathrm{~A}):: g f p$, xорE2(G2E)::gfp, xоpJ::gfp, xоpJ(G2E)::gfp, and gfp, respectively, under control of the Cauliflower mosaic virus $35 \mathrm{~S}$ promoter were infiltrated into N. benthamiana leaves. Samples were collected 30 (XopJ fusions) and 48 $\mathrm{h}$ postinoculation (XopE2 fusions), and equal protein amounts were analyzed by immunoblotting, using a GFP-specific antibody. Specific signals are marked with asterisks. B, XopE2 is acylated in the plant. XopE2::GFP and XopE2(G2A)::GFP samples prepared as in A were incubated in $0.5 \mathrm{M}$ hydroxylamine, $\mathrm{pH} 7$ (HA), or in $0.5 \mathrm{M}$ Tris, $\mathrm{pH} 7$ (Tris). Immunoblot analysis was carried out as in $\mathrm{A}$. 

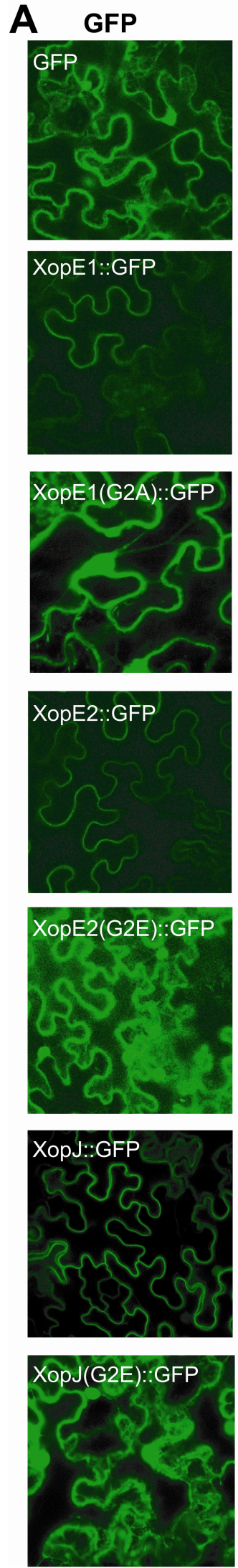

DAPI
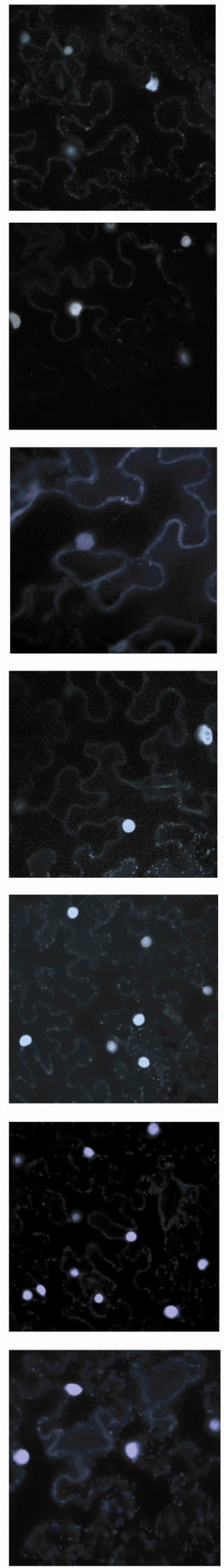

Merged
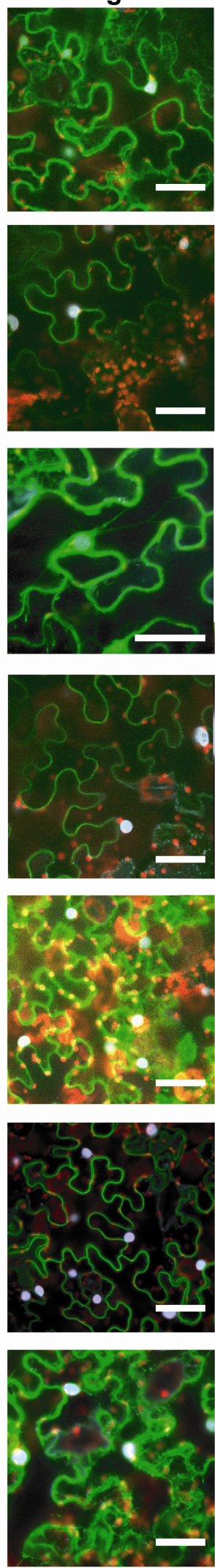

B
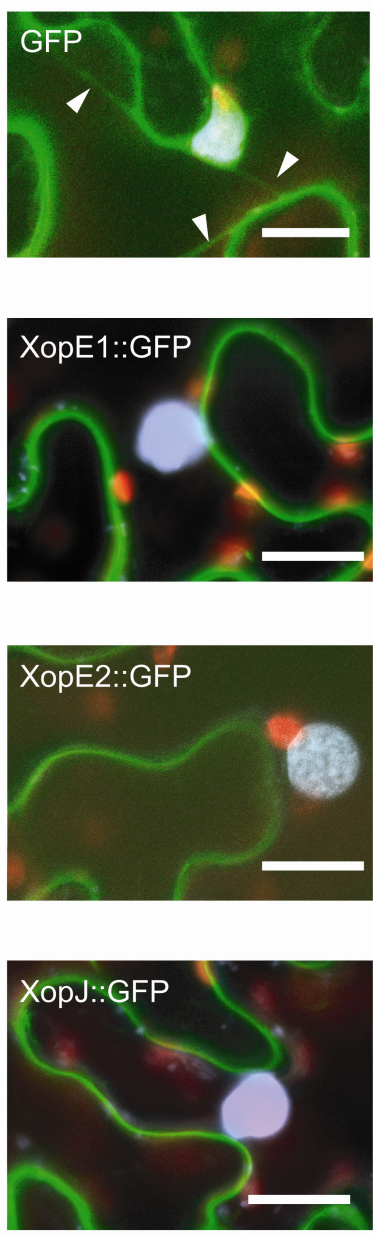

Fig. 3. Membrane localization of Xop::GFP fusions depends on the putative N-myristoylation motifs. Agrobacterium strains that mediate T-DNA-based transfer of $g f p, x o p E 1:: g f p, x o p E 1(\mathrm{G} 2 \mathrm{~A}):: g f p, x o p E 2:: g f p, x o p E 2(\mathrm{G} 2 \mathrm{E}):: g f p, x o p J:: g f p$, and $x o p J(\mathrm{G} 2 \mathrm{E}):: g f p$, respectively, were infiltrated into Nicotiana benthamiana leaves. For confocal laser scanning microscopy of lower epidermal cells, samples were taken 30 (XopE1 and XopJ fusions) and $48 \mathrm{~h}$ postinoculation (XopE2 fusions). A, GFP fluorescence is shown in green (left panel) and diamidin-2-phenylindol (DAPI)-staining of nuclei (white) in the second panel. The rightmost panel is a merged view including chloroplast autofluorescence (red). The size bars correspond to $50 \mu \mathrm{m}$. B, Magnifications of nucleus- and chloroplast-containing areas from the merged view in A, respectively. White arrows indicate cytoplasmic strands that span through the tonoplast. The size bars correspond to $20 \mu \mathrm{m}$. Note that, for XopE1::GFP, a different section from the same experiment is shown. 
phenotypes were analyzed further. The results of Agrobacterium-mediated expression assays could be reproduced with GFP-tagged and untagged protein variants.

As shown in Figure 6A, X. campestris pv. vesicatoria 85-10 triggered an HR in Solanum pseudocapsicum, whereas $85^{*} \Delta h r c V$ and the 85-10 xopE1/xopE2 double mutant derivative did not. Complementation assays showed that the double mutant $85-10 \Delta x o p E 1 \triangle x o p E 2$ could only be complemented by the $x o p E 2$ gene (Fig. 6A)

Agrobacterium-mediated expression of xopE1 and xopJ, respectively, triggered a cell death reaction in $N$. bentha- miana and $N$. clevelandii 3 to 4 days postinoculation (dpi) (Fig. 6B and C; data not shown). Interestingly, the mutant derivative XopE1(G2A) also triggered cell death in Nicotiana spp., but the reaction was faster and stronger (Fig. 6B). Immunoblot analyses showed that this phenotype was not due to higher expression levels of the XopE1(G2A) mutant version (Fig. 2A). These results suggest that cell death triggered by XopE1 is normally suppressed when the protein is targeted to the plasma membrane. In contrast, the $\mathrm{XopJ}(\mathrm{G} 2 \mathrm{E})$ mutant protein did not trigger cell death in Nicotiana spp. (Fig. 6C). Hence, the membrane localization
A
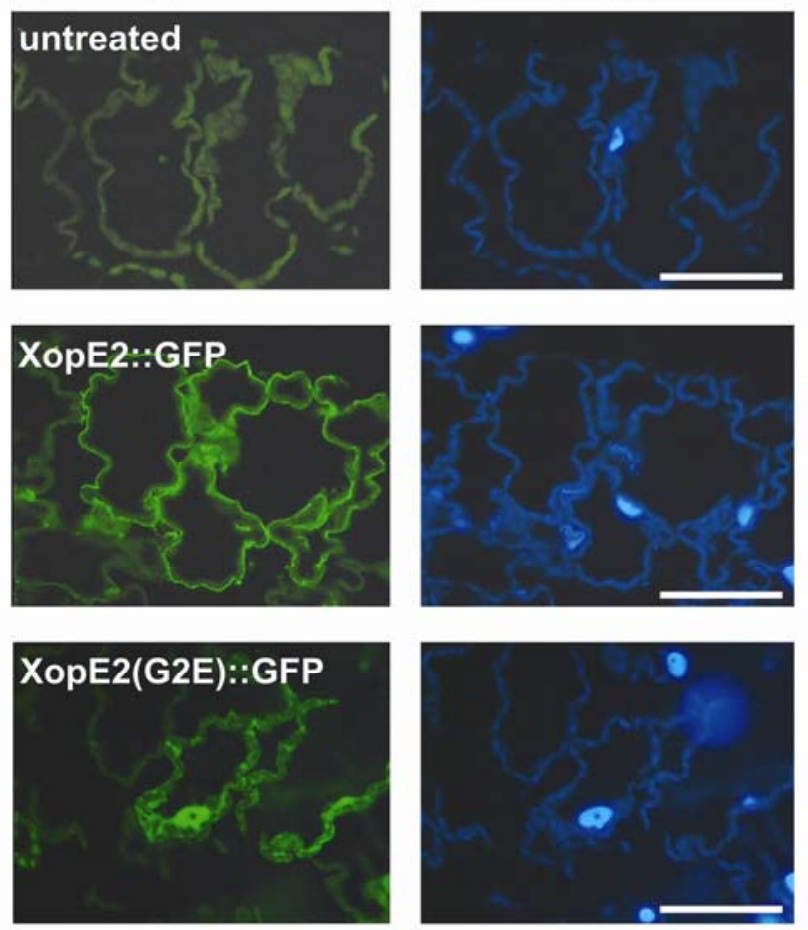

B

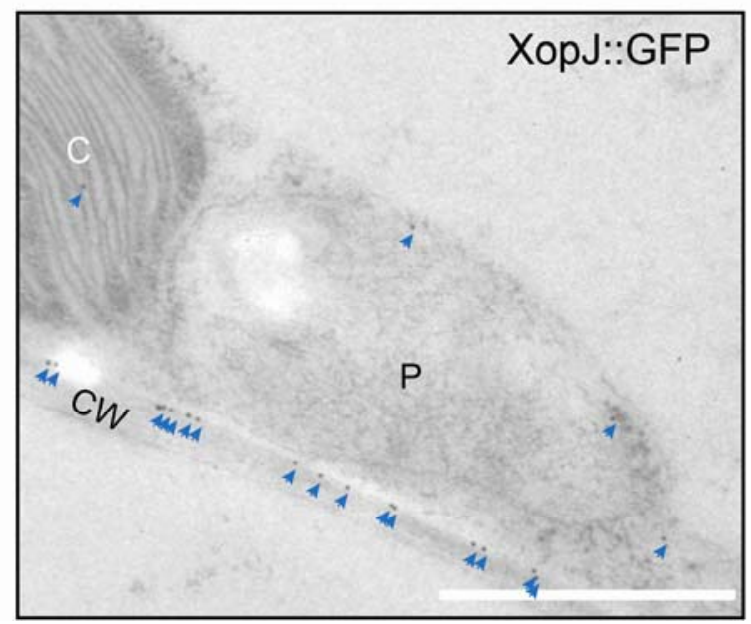

GFP
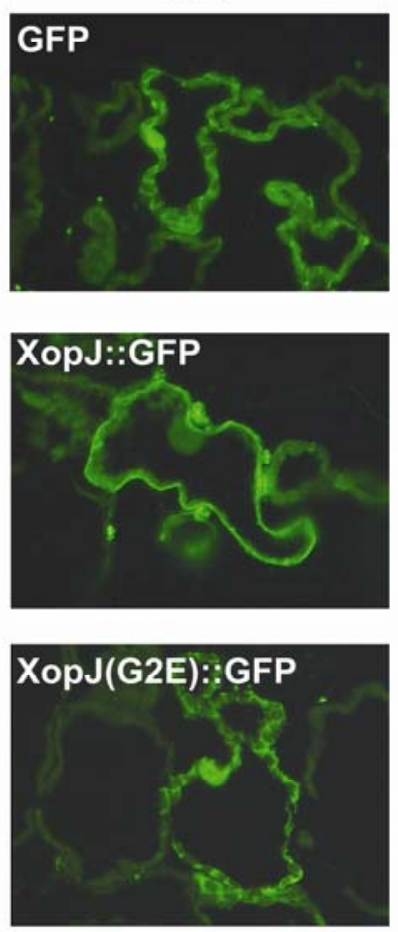

DAPI
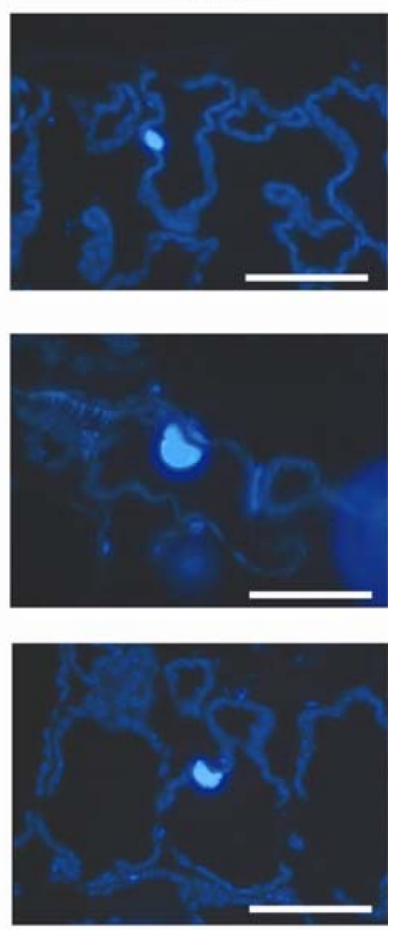

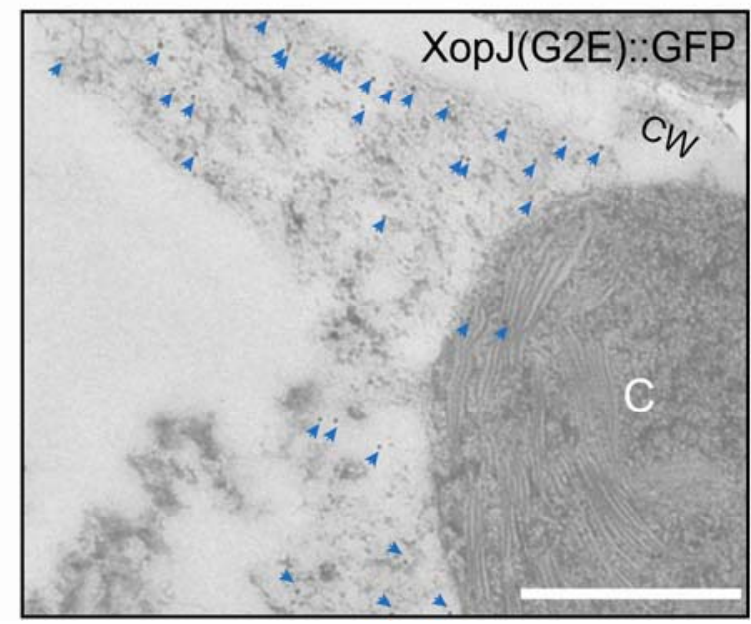

Fig. 4. Immunocytochemistry confirms N-myristoylation motif-dependent membrane localization of XopE2::GFP and XopJ::GFP fusions. Agrobacterium strains that mediate T-DNA-based transfer of $g f p$, xopE2::gfp, xopE2(G2E)::gfp, xopJ::gfp, and xopJ(G2E)::gfp, respectively, under control of the Cauliflower mosaic virus $35 \mathrm{~S}$ promoter were infiltrated into Nicotiana benthamiana leaves. Samples were taken $30 \mathrm{~h}$ postinoculation. A, GFP and GFP fusion proteins were visualized in mesophyll cells by immunofluorescence using anti-GFP and fluorescent Alexa 488 antibodies. Background of an untreated leaf area (pale green, upper left panel) and detection of GFP and fusion proteins (bright green) is shown in the left panel. The second panel shows diamidin2-phenylindol (DAPI) staining of the respective areas in the left panels. Nuclei appear blue. The size bars correspond to $50 \mu \mathrm{m}$. B, Ultrastructural localization of XopJ::GFP and XopJ(G2E)::GFP fusion proteins by transmission electron microscopy in mesophyll cells of N. benthamiana. Tissue samples were cryo-substituted and incubated with polyclonal anti-GFP antibody and a gold particle-conjugated secondary antibody. For the sake of clarity gold particles were marked with blue arrows. The size bars correspond to $500 \mathrm{~nm}$. $(\mathrm{C}=$ chloroplast, $\mathrm{CW}=$ cell wall, $\mathrm{P}=$ peroxisome $)$. 
of XopJ appears to be essential for the cell death reaction in Nicotiana spp.

\section{DISCUSSION}

In this study, we characterized two new type III effector genes, xopE1 and $x o p E 2$, which increases the number of known type III effectors in $X$. campestris pv. vesicatoria $85-10$ to a total of 17 proteins. Most type III effector genes discovered recently in Xanthomonas are coregulated with the T3S system (Noël et al. 2001, 2002, 2003). This is also true for xopE1 and xopE2, the promoter regions of which contain a PIP box. This conserved promoter motif has recently been shown to be bound by the AraC-type transcriptional activator HrpX (Koebnik et al. 2006).

XopE1 and XopE2 belong to the HopX effector family, which includes AvrPphE, HopX2, and homologs from subspecies of the plant pathogen genera Pseudomonas, Ralstonia, and Xanthomonas (Lindeberg et al. 2005; Rohmer et al. 2004). Members of the HopX family are part of the transglutaminase superfamily, and the respective conserved amino-acid residues are important for their function (Nimchuk et al. 2007). However, the transglutaminase superfamily encompasses proteins with different enzymatic functions, e.g., proteases, peptide N-glycanases, and DNA repair proteins (Anantharaman et al. 2001; Makarova et al. 1999). Due to the functional diversity of the transglutaminase family, the enzymatic activity of XopE1 and XopE2 is unclear and has to await biological data, i.e., identification of plant targets of XopE1 and XopE2.

Interestingly, all members of the HopX2 subgroup of the HopX family, including XopE1 and XopE2, possess a putative $\mathrm{N}$-myristoylation motif in their N-terminus (Table 1) that has not been studied so far. A homologous N-myristoylation motif was only found in one additional protein in $X$. campestris $\mathrm{pv}$. vesicatoria 85-10, XopJ, which belongs to the YopJ/AvrRxv effector family (Noël et al. 2003). Members of this family were thought to function as SUMO proteases (Orth et al. 2000; Roden et al. 2004a). However, it was recently shown that YopJ

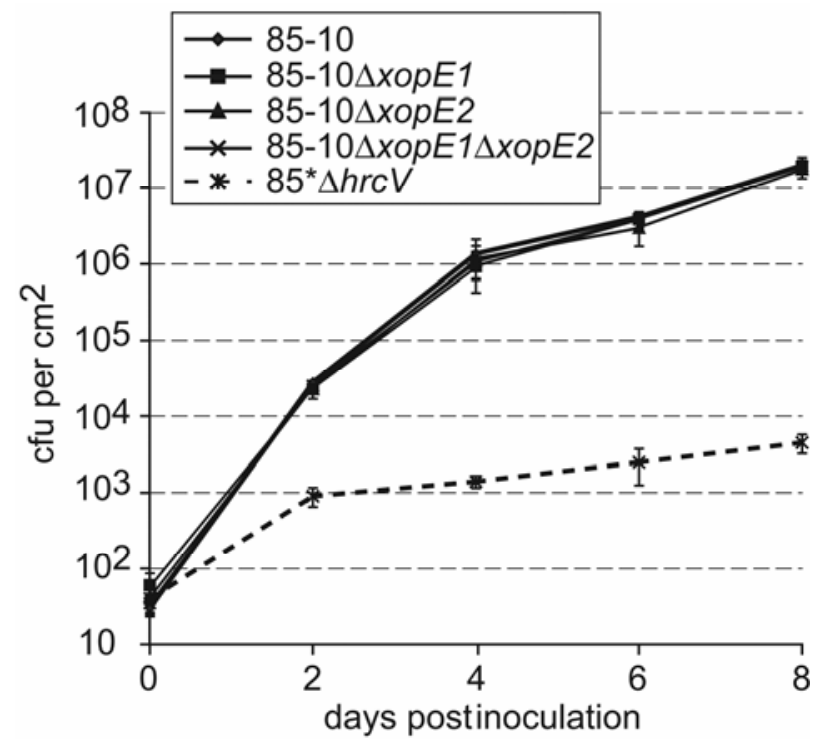

Fig. 5. Bacterial growth of Xanthomonas campestris pv. vesicatoria wild type and $x o p E 1$ and $x o p E 2$ mutant strains in susceptible pepper plants. $X$. campestris pv. vesicatoria 85-10 (wild type) and mutant strains

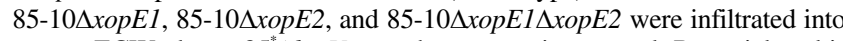
pepper ECW plants. $85^{*} \Delta h r c V$ served as a negative control. Bacterial multiplication was monitored over a period of eight days. Values represent the mean of three samples from three different plants. Error bars indicate the standard deviations. Results from one representative experiment are shown. from Yersinia spp. acts as an acetyltransferase on host cell mitogen-activated protein kinases involved in innate immunity (Mukherjee et al. 2006).

Microscopy analyses revealed that XopE1, XopE2 and XopJ localize to the plant cell plasma membrane, which is most likely due to an N-terminal acylation of the proteins mediated by the N-myristoylation motif (Figs. 3 and 4). Recognition of the N-myristoylation motif in the eukaryotic host cell leads to
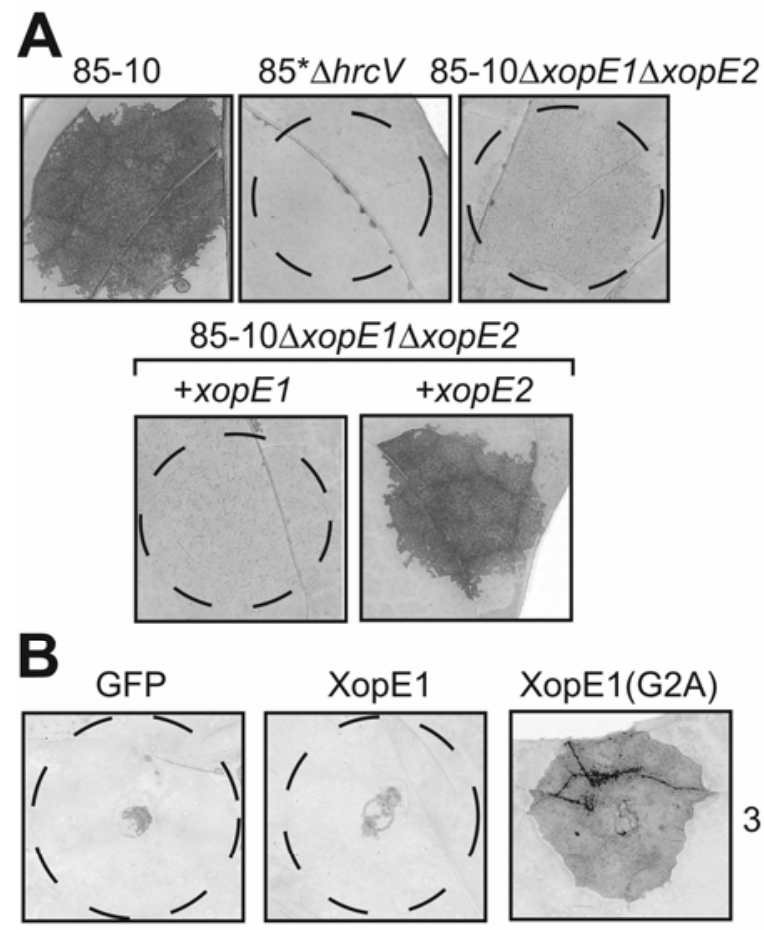

XopE1(G2A)
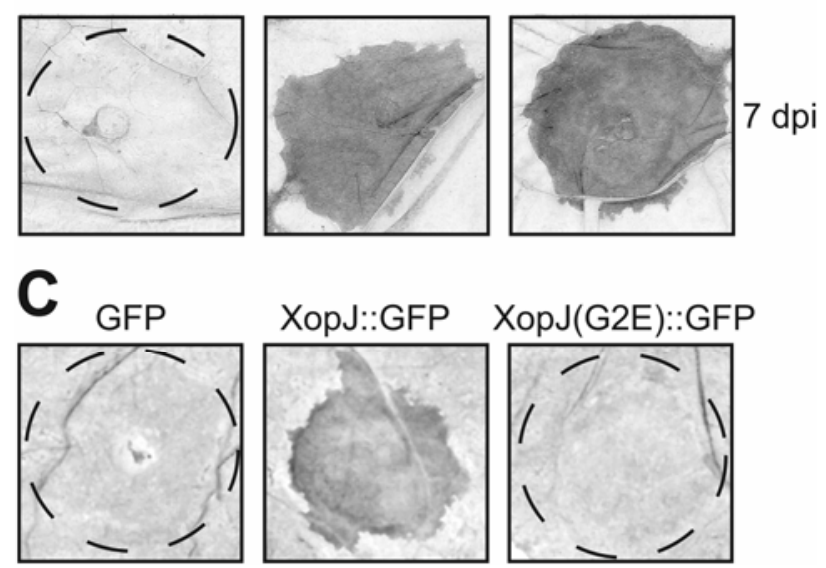

Fig. 6. XopE1, XopE2, and XopJ trigger cell death in different solanaceous plants. A, XopE2 triggers cell death in Solanum pseudocapsicum. X. campestris pv. vesicatoria 85-10, $85^{\circ} \Delta h r c V$, and the double mutant 85$10 \Delta x o p E 1 \Delta x o p E 2$ were infiltrated into Solanum pseudocapsicum. The latter strain was complemented using pDSK604 constructs that mediate xopE1 or $x o p E 2$ expression under control of their own promoters. Leaves were harvested 4 days postinoculation (dpi) and were bleached in ethanol for better visualization of the hypersensitive response. B, XopE1 triggers cell death in Nicotiana benthamiana. Agrobacterium strains that mediate T-DNA-based transfer of $g f p, x o p E 1$, and $x o p E 1(\mathrm{G} 2 \mathrm{~A})$, respectively, under control of the Cauliflower mosaic virus (CaMV) $35 \mathrm{~S}$ promoter were infiltrated into $\mathrm{N}$. benthamiana leaves. Leaves were harvested 4 and 7 dpi and were bleached in ethanol for better visualization of the cell death reactions. C, XopJ triggers cell death in Nicotiana benthamiana. Agrobacterium strains that mediate TDNA-based transfer of $g f p, x o p J:: g f p$, and $x o p J(\mathrm{G} 2 \mathrm{E}):: g f p$, respectively, under control of the CaMV 35S promoter were infiltrated into $N$. benthamiana leaves. Leaves were harvested $3 \mathrm{dpi}$ and were bleached in ethanol for better visualization of the cell death reactions. 
the attachment of the 14-carbon saturated fatty acid myristate at the N-terminal glycine residue (Farazi et al. 2001). Indeed, the membrane localization of XopE1, XopE2, and XopJ was dependent on the N-terminal glycine residue (G2) (Figs. 3 and 4). Besides the myristoyl anchor, additional membrane attachment factors are often found, e.g., palmitoylation of a cysteine residue (Table 1). The latter modifications are required for stable binding of the target protein to the membrane (MaurerStroh and Eisenhaber 2004). Our finding that hydroxylamine treatment of plant extracts containing the XopE2::GFP protein resulted in a shift in molecular mass of XopE2 strongly suggests that palmitate is covalently linked by a thioester bond to the cysteine residue at amino-acid position 4 (Table 1), a modification which is also discussed for other effector proteins (Maurer-Stroh and Eisenhaber 2004). In animal cells, such dual acylation (myristoylation and palmitoylation) can direct proteins to lipid rafts, specialized membrane microdomains in which signaling molecules are often concentrated (Zacharias et al. 2002). Recently, lipid rafts were also described for plant plasma membranes (Borner et al. 2005), but their role in the interaction with pathogens has not been elucidated yet.

To address the biochemical function of bacterial effectors and the relevance of modifications like N-myristoylation, it is crucial to identify specific effects of the Xops in the plant. However, neither xopE1 and xopE2 single and double mutant strains nor a xopJ frameshift mutant (Noël et al. 2003) were affected in bacterial growth and symptom formation on susceptible pepper plants under the conditions tested. The same holds true for a mutant in the $X$. campestris pv. campestris HopX2 homolog avrXccE1 (Castañeda et al. 2005). These results suggest subtle contributions of the effectors under study to bacterial virulence or functional redundancy, which is discussed for many type III effectors (Alfano and Collmer 2004). Because the host plant $C$. annuum did not show visible reactions triggered by the effectors tested here, we inoculated Xanthomonas mutant and Agrobacterium strains into 17 different solanaceous species. This approach identified cell death-triggering activities for all three effectors in different plant species. Agrobacterium-mediated expression of XopE1 and XopJ triggered a fast cell-death reaction in nonhost Nicotiana plants that was enhanced with the myristoylation-motif mutant XopE1(G2A) but abolished for the $\mathrm{XopJ}(\mathrm{G} 2 \mathrm{E})$ mutant version. These results suggest that XopE1 and XopJ are recognized in Nicotiana species. In the case of XopE1, the membrane localization delays the detection by the plant surveillance system, which could be of importance for the pathogen. If an effector can escape detection until other effector proteins have suppressed plant defense, the former effector might not be recognized (Mudgett 2005; Grant et al. 2006). In contrast to XopE1, the recognition of XopJ in Nicotiana species is completely dependent on the localization at the plant plasma membrane or on its function at the membrane. Similar results were described for the Pseudomonas effectors AvrPto, AvrRpm1, AvrB, and HopF (Nimchuk et al. 2000; Robert-Seilaniantz et al. 2006; Shan et al. 2000). For XopE2 an avirulence activity in the ornamental plant S. pseudocapsicum was identified. Based on our unpublished results, this reaction seems to be independent of the N-myristoylation motif. Specific recognition in the plant often but not always depends on the correct localization of the respective effector protein, e.g., the Xanthomonas effector AvrBs4 localizes to the nucleus but is recognized in the cytoplasm (Schornack et al. 2006).

How common is N-myristoylation of type III effectors? Membrane targeting in the host plant cell mediated by $\mathrm{N}$ myristoylation was described previously only for some type III effectors from the plant pathogen $P$. syringae (Nimchuk et al. 2000; Robert-Seilaniantz et al. 2006; Shan et al. 2000). How- ever, analysis of recently published Xanthomonas and Pseudomonas spp. genome sequences revealed a number of bona fide or putative effectors with N-myristoylation signals that are homologous to the motif described here (Table 1). In conclusion, membrane localization of effectors due to $\mathrm{N}$-myristoylation appears to be quite common. It is noteworthy that N-myristoylation motifs are often conserved in different effectors and that they overlap with the putative $\mathrm{N}$-terminal T3S signal, which is usually not conserved (Alfano and Collmer 2004). This finding suggests that such effectors have evolved by terminal reassortment, a proposed shuffling process that mobilizes T3S signals in the genome and creates new chimeric effector genes (Stavrinides et al. 2006).

In conclusion, XopE1, XopE2, and XopJ are the first Xanthomonas effectors that are targeted to the plant plasma membrane, most likely mediated by $\mathrm{N}$-myristoylation. The next challenge is the identification of plant target proteins of XopE1, XopE2, and XopJ, which is crucial to elucidate their molecular function.

\section{MATERIALS AND METHODS}

Bacterial strains and growth conditions.

Escherichia coli cells were cultivated at $37^{\circ} \mathrm{C}$ in lysogenicbroth medium, A. tumefaciens at $30^{\circ} \mathrm{C}$ in YEB medium $(0.5 \%$ BACTO beef extract, $1 \%$ BACTO yeast extract, $0.5 \%$ BACTO peptone, $0.5 \%$ saccharose, $0.2 \% 1 \mathrm{M} \mathrm{MgSO}_{4}, \mathrm{pH} 7.2$ ) and $X$. campestris pv. vesicatoria at $30^{\circ} \mathrm{C}$ in $\mathrm{NYG}$ or in minimal medium A (Ausubel et al. 1996) supplemented with sucrose $(10 \mathrm{mM})$ and casamino acids $(0.3 \%)$. Plasmids were introduced into E. coli, A. tumefaciens, and X. campestris pv. vesicatoria by electroporation using a Bio-Rad 'MicroPulser' (Bio-Rad Laboratories, Munich, Germany) according to manufacturer protocols. Plasmids were also introduced into $X$. campestris pv. vesicatoria by conjugation, using pRK2013 as a helper plasmid in triparental matings (Ditta et al. 1980; Figurski and Helinski 1979).

Antibiotics were added to the media at the following final concentrations: ampicillin, $100 \mu \mathrm{g} / \mathrm{ml}$; chloramphenicol, 30 $\mu \mathrm{g} / \mathrm{ml}$; hygromycin $150 \mu \mathrm{g} / \mathrm{ml}$; kanamycin, $25 \mu \mathrm{g} / \mathrm{ml}$ (for Agrobacterium $100 \mu \mathrm{g} / \mathrm{ml}$ ); rifampicin, $100 \mu \mathrm{g} / \mathrm{ml}$; spectinomycin, $100 \mu \mathrm{g} / \mathrm{ml}$; tetracycline, $10 \mu \mathrm{g} / \mathrm{ml}$; cycloheximide, 500 $\mu \mathrm{g} / \mathrm{ml}$.

\section{Plant material and inoculations.}

Xanthomonas inoculation into the near-isogenic pepper cultivars ECW, ECW-10R, ECW-30R (Minsavage et al. 1990), and other plants were performed as described previously (Bonas et al. 1991). Translocation assays were carried out as described (Noël et al. 2003). Leaves were harvested 2 dpi and were bleached with ethanol to facilitate better visualization of the HR. To determine the in planta growth of Xanthomonas cells, the method described for Pseudomonas syringae (Katagiri et al. 2002) was adapted. Bacteria were infiltrated at $5 \times 10^{4} \mathrm{CFU} / \mathrm{ml}$ into ECW plants. Samples were collected 0, 2, 4, 6, and 8 dpi. For each strain, three leaf disks of $0.5 \mathrm{~cm}^{2}$ were harvested and ball-milled (Rentsch GmbH, Haan, Germany) in $100 \mu \mathrm{l}$ of 10 $\mathrm{mM} \mathrm{MgCl} 2$ at $30 \mathrm{~Hz}$ for $40 \mathrm{~s}$, and $10 \mu \mathrm{l}$ of 10 -fold dilutions up to $10^{-8}$ were dropped onto selective NYG agar.

For A. tumefaciens-mediated transient expression studies, we used strain GV3101 (Van Larebeke et al. 1974). Agrobacterium suspensions $\left(\mathrm{OD}_{600}=0.8\right)$ were incubated for $3 \mathrm{~h}$ at room temperature in infiltration medium (Van den Ackerveken et al. 1996), prior to inoculation into leaves with a needleless syringe.

Plants were kept at $20^{\circ} \mathrm{C}, 70 \%$ relative humidity and with $16 \mathrm{~h}$ light. Tested solanaceous species included Brugmansia spp., Capsicum annuum, Lycopersicon esculentum MM, Ly- 
copersicon pennellii LA2963, Mandragora spp., Nicandra physaloides, Nicotiana benthamiana, N. clevelandii, N. tabacum cv. Havanna, Petunia spp., Physalis alkekengi, Physalis peruviana, Solanum aviculare, S. nigrum, S. americanum, S. pseudocapsicum, S. suaveolens, and S. tuberosum. Each species was tested twice and the development of the HR and disease symptoms were monitored over a period of $8 \mathrm{dpi}$.

\section{Construction of AvrBs3 $3 \Delta 2$ fusion proteins.}

To create translational fusions with $\operatorname{avrBs} 3 \Delta 2$, the promoters and $5^{\prime}$ coding sequences of xop genes were amplified by PCR from genomic DNA of $X$. campestris pv. vesicatoria 85-10, were cloned into pENTR/D-TOPO (Invitrogen, Karlsruhe, Germany), and were recombined into pL6GW356 (Noël et al. 2003). The PCR products contained the first 135 codons and 1,001-bp upstream sequence of xopE 1 and the first 150 codons and 1,018-bp upstream sequence of xopE2, respectively. Oligonucleotide sequences are listed in Table 2.

\section{Protein analyses.}

Xanthomonas in vitro secretion experiments and Western blot analyses were performed as described (Rossier et al. 1999). For Agrobacterium-mediated expression studies, samples (two $0.8-\mathrm{cm}^{2}$ leaf disks) were collected 30 to $48 \mathrm{~h}$ postinoculation, were frozen in liquid nitrogen, were ground and resuspended in $120 \mu \mathrm{l}$ of $8 \mathrm{M}$ urea and $30 \mu \mathrm{l}$ of $5 \times$ Laemmli buffer, and were boiled for $10 \mathrm{~min}$. Proteins were separated on a $12 \%$ polyacrylamide gel and were blotted to a PROTRAN membrane (Schleicher and Schuell, Dassel, Germany). For detection of AvrBs3 (Knoop et al. 1991), HrcN (Rossier et al. 2000) and GFP (Invitrogen, Karlsruhe, Germany) specific polyclonal antisera and horse-radish peroxidase-labeled goat $\alpha$-rabbit antiserum (Amersham Pharmacia Biotech, Piscataway, NJ, U.S.A.) were used. Reactions were visualized by enhanced chemiluminescence (Amersham Pharmacia Biotech).

For the release of thioester bonds, hydroxylamine $(\mathrm{pH} 7)$ was added to the plant protein extracts to a final concentration of $0.5 \mathrm{M}$. Samples were incubated for $2 \mathrm{~h}$ at $22^{\circ} \mathrm{C}$ before loading.

\section{RNA analyses.}

RNA extraction, cDNA synthesis, and RT-PCR experiments were performed as described (Noël et al. 2001). Experiments were performed at least three times for each gene with two independent cDNA preparations each. Oligonucleotide sequences are listed in Table 2.

\section{Generation of $x o p E 1$ and $x o p E 2$ mutants and complementation studies.}

To mutate xopE1, a deletion of 1,194 bp encompassing the complete gene with exception of the start and stop codon was generated. For this, a 1,000-bp fragment upstream and a 998bp fragment downstream of xopE1 were amplified from genomic DNA of $X$. campestris pv. vesicatoria 85-10 using oligonucleotides (Table 2) harboring appropriate restriction sites. To generate a 1,071-bp deletion encompassing the xopE2 gene between start and stop codon, a 999-bp fragment upstream and a 1,000-bp fragment downstream were amplified from $X$. campestris pv. vesicatoria 85-10 genomic DNA (Table 2). The PCR fragments were cloned into pBluescriptIIKS giving $\mathrm{pKS} \Delta \mathrm{xopE1}$ and $\mathrm{pKS} \Delta \mathrm{xopE2}$. The 2-kb SalI/XbaI deletion fragments of $\mathrm{pKS} \Delta \mathrm{xopE} 1$ and $\mathrm{pKS} \Delta \mathrm{xopE} 2$ were ligated into the suicide vector $\mathrm{pK} 18 \mathrm{mob}: \mathrm{sacB}$ (Schäfer et al. 1994), resulting in pK18E1 and pK18E2, and were electroporated into $X$. campestris pv. vesicatoria 85-10. The deletions were ultimately introduced via double crossing-over into the chromosome. The resulting strains (85-10 $x$ xopE1, 85-10 $\triangle x o p E 2$, and 85$10 \Delta x o p E 1 \Delta x o p E 2)$ were identified by PCR and Southern blot
Table 2. Oligonucleotides used in this study

\begin{tabular}{|c|c|c|}
\hline Name & Sequence & Features $^{\mathbf{a}}$ \\
\hline \multicolumn{3}{|c|}{ Construction of $A v r B s 3 \Delta 2$ fusions } \\
\hline xopE1 forward & $\begin{array}{l}\text { caccTGCCGTGATGGAAG } \\
\text { GCGGCAC }\end{array}$ & $\begin{array}{l}\text { Directional } \\
\text { TOPO site }\end{array}$ \\
\hline xopE1 reverse & $\begin{array}{l}\text { AGACAGGTAACTACAG } \\
\text { GTGGAG }\end{array}$ & \\
\hline xopE2 forward & $\begin{array}{l}\text { caccCCTTCCTGGGGTTCA } \\
\text { GCCGTTC }\end{array}$ & $\begin{array}{l}\text { Directional } \\
\text { TOPO site }\end{array}$ \\
\hline xopE2 reverse & $\begin{array}{l}\text { GCTGCCCGCCAGTAAAT } \\
\text { TTTC }\end{array}$ & $\ldots$ \\
\hline \multicolumn{3}{|c|}{ Reverse-transcription-polymerase chain reaction analyses } \\
\hline RT_xopE1 forward & $\begin{array}{l}\text { CATTTCAAAGCCGGCGA } \\
\text { TGTC }\end{array}$ & $\ldots$ \\
\hline RT_xopE1 reverse & $\begin{array}{l}\text { GTACATGTGGGCGCACG } \\
\text { CTTG }\end{array}$ & $\ldots$ \\
\hline RT_xopE2 forward & $\begin{array}{l}\text { AGTTCAAAGCCGAGCGT } \\
\text { GGTG }\end{array}$ & $\ldots$ \\
\hline RT_xopE2 reverse & $\begin{array}{l}\text { GCTGCCCGCCAGTAAAT } \\
\text { TTTC }\end{array}$ & $\cdots$ \\
\hline RT_16SrRNA forward & $\begin{array}{l}\text { TACGCTAATACCGCATA } \\
\text { CGAC }\end{array}$ & $\cdots$ \\
\hline RT_16SrRNA reverse & $\begin{array}{l}\text { TGGCACGAAGTTAGCCG } \\
\text { GTG }\end{array}$ & $\ldots$ \\
\hline \multicolumn{3}{|c|}{ Generation of mutations in $x о p E 1$ and $x о p E 2$} \\
\hline$\Delta$ xopE1_1 & $\begin{array}{l}\text { ACGCgtcgacGTGATGGAA } \\
\text { GGCGGCACCGTC }\end{array}$ & SalI site \\
\hline$\Delta$ xopE1_2 & $\begin{array}{l}\text { CCCaagcttCATGTCGCTCT } \\
\text { CCGATCATG }\end{array}$ & HindIII site \\
\hline$\Delta$ xopE1_3 & $\begin{array}{l}\text { CCCaagcttAGATGAACGC } \\
\text { CCCTTCGATC }\end{array}$ & HindIII site \\
\hline$\Delta$ xopE1_4 & $\begin{array}{l}\text { CGCggatccCAGGCCACCA } \\
\text { GCAGCCACAAC }\end{array}$ & BamHI site \\
\hline$\Delta$ xopE2_1 & $\begin{array}{l}\text { ACGCgtcgacCTGGGGTTC } \\
\text { AGCCGACATAC }\end{array}$ & SalI site \\
\hline$\Delta x o p E 2 \_2$ & $\begin{array}{l}\text { CCCaagcttCATCTTGATCT } \\
\text { CCTGCAGTGAC }\end{array}$ & HindIII site \\
\hline$\Delta$ xopE2_3 & $\begin{array}{l}\text { CCCaagcttTGACGATGGA } \\
\text { TCAAGCCGGATG }\end{array}$ & HindIII site \\
\hline$\Delta$ xopE2_4 & $\begin{array}{l}\text { CGCggatccCGCCTGGACG } \\
\text { AACTCGCCCAG }\end{array}$ & BamHI site \\
\hline \multicolumn{3}{|c|}{ Complementation of the xopE1xopE2 double mutant } \\
\hline xopE1 promoter forward & $\begin{array}{l}\text { GgaattcTGCCGTGATGGA } \\
\text { AGGCGGCAC }\end{array}$ & EcoRI site \\
\hline xopE1 reverse & $\begin{array}{l}\text { CCCaagcttTCATCTCGCCA } \\
\text { CCGTGACAGG }\end{array}$ & HindIII site \\
\hline xopE2 promoter forward & $\begin{array}{l}\text { GgaattcCTTCCTGGGGTTC } \\
\text { AGCCGTTC }\end{array}$ & EcoRI site \\
\hline xopE2 reverse & $\begin{array}{l}\text { CCCaagcttTCACCAACTC } \\
\text { AAGGGTGGGCG }\end{array}$ & HindIII site \\
\hline \multicolumn{3}{|c|}{ Generation of XopE1 and XopE2 GFP fusions } \\
\hline xopE1 forward & $\begin{array}{l}\text { caccATGGGACTATGCAT } \\
\text { TTCAAAG }\end{array}$ & $\begin{array}{l}\text { Directional } \\
\text { TOPO site }\end{array}$ \\
\hline xopE1 reverse & $\begin{array}{l}\text { TCTCGCCACCGTGACAG } \\
\text { GCGG }\end{array}$ & \\
\hline xopE1(stop) reverse & $\begin{array}{l}\text { CGTTCATCTCGCCACCG } \\
\text { TGAC }\end{array}$ & \\
\hline xopE2 forward & $\begin{array}{l}\text { caccATGGGGCTATGCAG } \\
\text { TTCAAAG }\end{array}$ & $\begin{array}{l}\text { Directional } \\
\text { TOPO site }\end{array}$ \\
\hline xopE2 reverse & $\begin{array}{l}\text { CCAACTCAAGGGTGGGC } \\
\text { GAC }\end{array}$ & \\
\hline xopE2(stop) reverse & $\begin{array}{l}\text { GATCCATCGTCACCAAC } \\
\text { TCAAG }\end{array}$ & $\begin{array}{l}\text { Directional } \\
\text { TOPO site }\end{array}$ \\
\hline xopJ forward & $\begin{array}{l}\text { caccATGGGTCTATGCGT } \\
\text { TTCAAAGCCGAG }\end{array}$ & $\begin{array}{l}\text { Directional } \\
\text { TOPO site }\end{array}$ \\
\hline xорJ reverse & $\begin{array}{l}\text { TGACTGGCGATCAGAGA } \\
\text { TAGCTGTCTCCAG }\end{array}$ & \\
\hline xopE1(G2A) forward & $\begin{array}{l}\text { caccATGGctCTATGCATT } \\
\text { TCAAAGCC }\end{array}$ & $\begin{array}{l}\text { Directional } \\
\text { TOPO site }\end{array}$ \\
\hline xopE2(G2A) forward & $\begin{array}{l}\text { caccATGGcGCTATGCAGT } \\
\text { TCAAAG }\end{array}$ & $\begin{array}{l}\text { Directional } \\
\text { TOPO site }\end{array}$ \\
\hline xopE2(G2E) forward & $\begin{array}{l}\text { caccATGGaGCTATGCAGT } \\
\text { TCAAAGCCGAG }\end{array}$ & $\begin{array}{l}\text { Directional } \\
\text { TOPO site }\end{array}$ \\
\hline xopJ $(G 2 E)$ forward & $\begin{array}{l}\text { caccATGGaGCTATGCGTT } \\
\text { TCAAAGCCGAG }\end{array}$ & $\begin{array}{l}\text { Directional } \\
\text { TOPO site }\end{array}$ \\
\hline
\end{tabular}

${ }^{a}$ Special features of the oligonucleotides are indicated by lower case letters. 
analysis. For complementation, fragments containing the promoters and coding sequences of $x o p E 1$ and $x o p E 2$ were amplified by PCR from genomic DNA of $X$. campestris pv. vesicatoria 85-10 and were cloned into pDSK602 (Murillo et al. 1994) using the EcoRI and HindIII site introduced by the oligonucleotides (Table 2). The resulting plasmids were conjugated into strain 85-10 $\triangle x o p E 1 \Delta x o p E 2$.

\section{Generation of $x o p E 1, x o p E 2$, and $x o p J$ expression and GFP fusion constructs.}

To create expression constructs and translational fusions to GFP the xopE1, xopE2, and xopJ genes were amplified with and without stop codons from genomic DNA of $X$. campestris pv. vesicatoria 85-10, were cloned into $\mathrm{pENTR/D-TOPO}$ (Invitrogen), and were sequenced and recombined into pGWB5 (T. Nakagawa, Research Institute of Molecular Genetics, Matsue, Japan) or pK7FWG2 (Karimi et al. 2002), which, for fragments without stop codon, results in a C-terminal GFPtag. Point mutations in xopE1, xopE2, and xopJ were introduced using modified forward oligonucleotides (Table 2).

\section{Confocal laser scanning microscopy and immunocytochemistry of Xop::GFP fusions.}

Subcellular localization of GFP and GFP fusions in N. benthamiana lower epidermal cells were inspected using the confocal laser scanning microscope LSM 510 and the software LSM Image Browser (Carl Zeiss GmbH, Göttingen, Germany) according to protocols from the manufacturer. To visualize plant cell nuclei, samples were treated with a $0.1 \%$ DAPI solution.

For immunofluorescence, leaf segments were fixed for $2 \mathrm{~h}$ at room temperature in phosphate buffered saline (PBS) containing 3\% paraformaldehyde and $0.05 \%$ Triton, were dehydrated in ethanol, and were embedded in polyethylene glycol 1500 at $46^{\circ} \mathrm{C}$. Thin sections $(3 \mu \mathrm{m})$ were transferred to poly-Llysine coated slides, were washed with PBS, and were blocked with $0.1 \mathrm{M} \mathrm{NH}_{4} \mathrm{Cl}$. After additional washing with PBS and blocking with $5 \%$ bovine serum albumin, the slides were incubated overnight at $4{ }^{\circ} \mathrm{C}$ with polyclonal $\alpha$-GFP antibody (Clontech-Europe, St. Germain, France). Sections were washed and incubated with secondary antibody (goat $\alpha$-rabbit immunoglobulin G conjugated to Alexa Fluor 488; Invitrogen) for 90 min at $37^{\circ} \mathrm{C}$. Sections were stained with DAPI, were enclosed with Citiflour/Glycerol, and were inspected with a fluorescence microscope (Axioskop 20, Carl Zeiss, Jena, Germany).

For ultrastructural localization, 2-mm leaf disks were prepared with a biopsy punch, were vacuum-infiltrated with $8 \%$ methanol, were transferred into aluminum planchettes, and were frozen under high pressure with an HPM 10 (BAL-TEC, Balzers, Lichtenstein). The specimens were cryo-substituted for 4 days at $-80^{\circ} \mathrm{C}$ in acetone containing $0.25 \%$ glutaraldehyde and $0.1 \%$ uranyl acetate, using an FSU (BAL-TEC). After embedding in HM20 (Polysciences Europe, Eppelheim, Germany), ultrathin sections were immunolabeled using a polyclonal $\alpha$-GFP antibody and goat $\alpha$-rabbit IgG conjugated to $10-n m$ gold particles (Sigma, Taufkirchen, Germany). After staining with uranyl acetate and lead citrate in an EM-Stain apparatus (Leica, Bensheim, Germany), sections were examined using an EM 900 transmission electron microscope (Carl Zeiss NTS, Oberkochen, Germany). Micrographs were taken with a Variospeed SSCCD (TRS, Dünzelbach, Germany).

\section{Bioinformatic approaches.}

Sequence homology searches were conducted using BLAST (Ye et al. 2006). For motif searches, we used MEROPS (Rawlings et al. 2006) and InterPro (Mulder et al. 2007). Nmyristoylation motifs were predicted using NMT (Eisenhaber et al. 2003) and Myristoylator (Bologna et al. 2004).

\section{ACKNOWLEDGMENTS}

We thank R. Koebnik for helpful discussions, S. Kay, D. Büttner, and J. Boch for critical reading of the manuscript, and C. Kretschmer, S. Jahn, and B. Rosinsky for excellent technical assistance. This work was funded by grants from the Deutsche Forschungsgemeinschaft (SFB 648) and the Federal Ministry of Education and Research (BMBF, GenoMik-1 Plus initiative) to U. Bonas.

\section{LITERATURE CITED}

Abramovitch, R. B., Janjusevic, R., Stebbins, C. E., and Martin, G. B. 2006. Type III effector AvrPtoB requires intrinsic E3 ubiquitin ligase activity to suppress plant cell death and immunity. Proc. Natl. Acad. Sci. U.S.A. 103:2851-2856.

Alfano, J. R., and Collmer, A. 2004. Type III secretion system effector proteins: Double agents in bacterial disease and plant defense. Annu. Rev. Phytopathol. 42:385-414.

Anantharaman, V., Koonin, E. V., and Aravind, L. 2001. Peptide-N-glycanases and DNA repair proteins, $\mathrm{Xp}-\mathrm{C} / \mathrm{Rad} 4$, are, respectively, active and inactivated enzymes sharing a common transglutaminase fold. Hum. Mol. Genet. 10:1627-1630.

Arnold, D. L., Jackson, R. W., Fillingham, A. J., Goss, S. C., Taylor, J. D., Mansfield, J. W., and Vivian, A. 2001. Highly conserved sequences flank avirulence genes: Isolation of novel avirulence genes from Pseudomonas syringae pv. pisi. Microbiol. 147:1171-1182.

Ausubel, F. M., Brent, R., Kingston, R. E., Moore, D. D., Seidman, J. G., Smith, J. A., and Struhl, K. 1996. Current Protocols in Molecular Biology. John Wiley \& Sons, Inc., New York

Bologna, G., Yvon, C., Duvaud, S., and Veuthey, A. L. 2004. N-Terminal myristoylation predictions by ensembles of neural networks. Proteomics 4:1626-1632.

Bonas, U., Schulte, R., Fenselau, S., Minsavage, G. V., Staskawicz, B. J., and Stall, R. E. 1991. Isolation of a gene-cluster from Xanthomonas campestris pv. vesicatoria that determines pathogenicity and the hypersensitive response on pepper and tomato. Mol. Plant-Microbe Interact. 4:81-88.

Borner, G. H., Sherrier, D. J., Weimar, T., Michaelson, L. V., Hawkins, N. D., Macaskill, A., Napier, J. A., Beale, M. H., Lilley, K. S., and Dupree, P. 2005. Analysis of detergent-resistant membranes in Arabidopsis. Evidence for plasma membrane lipid rafts. Plant Physiol. 137:104-116.

Büttner, D., and Bonas, U. 2006. Who comes first? How plant pathogenic bacteria orchestrate type III secretion. Curr. Opin. Microbiol. 9:193200.

Büttner, D., Nennstiel, D., Klüsener, B., and Bonas, U. 2002. Functional analysis of HrpF, a putative type III translocon protein from Xanthomonas campestris pv. vesicatoria. J. Bacteriol. 184:2389-2398.

Castañeda, A., Reddy, J. D., El-Yacoubi, B., and Gabriel, D. W. 2005. Mutagenesis of all eight avr genes in Xanthomonas campestris pv. campestris had no detected effect on pathogenicity, but one avr gene affected race specificity. Mol. Plant-Microbe Interact. 18:1306-1317.

Chang, J. H., Urbach, J. M., Law, T. F., Arnold, L. W., Hu, A., Gombar, S., Grant, S. R., Ausubel, F. M., and Dangl, J. L. 2005. A high-throughput, near-saturating screen for type III effector genes from Pseudomonas syringae. Proc. Natl. Acad. Sci. U.S.A. 102:2549-2554.

Daniels, M. J., Barber, C. E., Turner, P. C., Sawczyc, M. K., Byrde, R. J. W., and Fielding, A. H. 1984. Cloning of genes involved in pathogenicity of Xanthomonas campestris pv. campestris using the broad host range cosmid pLAFR1. EMBO (Eur. Mol. Biol. Organ.) J. 3:33233328.

Ditta, G., Stanfield, S., Corbin, D., and Helinski, D. 1980. Broad host range DNA cloning system for gram-negative bacteria: Construction of a gene bank of Rhizobium meliloti. Proc. Natl. Acad. Sci. U.S.A. 77:7347-7351.

Eisenhaber, F., Eisenhaber, B., Kubina, W., Maurer-Stroh, S., Neuberger, G., Schneider, G., and Wildpaner, M. 2003. Prediction of lipid posttranslational modifications and localization signals from protein sequences: Big-Pi, NMT and PTS1. Nucleic Acids Res. 31:3631-3634.

Farazi, T. A., Waksman, G., and Gordon, J. I. 2001. The biology and enzymology of protein N-myristoylation. J. Biol. Chem. 276:39501-39504.

Figurski, D., and Helinski, D. R. 1979. Replication of an origin-containing derivative of plasmid RK2 dependent on a plasmid function provided in trans. Proc. Natl. Acad. Sci. U.S.A. 76:1648-1652.

Fouts, D. E., Abramovitch, R. B., Alfano, J. R., Baldo, A. M., Buell, C. R. Cartinhour, S., Chatterjee, A. K., D'Ascenzo, M., Gwinn, M. L. Lazarowitz, S. G., Lin, N. C., Martin, G. B., Rehm, A. H., Schneider, D. J., van Dijk, K., Tang, X., and Collmer, A. 2002. Genomewide identification of Pseudomonas syringae pv. tomato DC3000 promoters controlled by the HrpL alternative sigma factor. Proc. Natl. Acad. Sci. 
U.S.A. 99:2275-2280.

Grant, S. R., Fisher, E. J., Chang, J. H., Mole, B. M., and Dangl, J. L. 2006. Subterfuge and manipulation: Type III effector proteins of phytopathogenic bacteria. Annu. Rev. Microbiol. 60:425-449.

Gürlebeck, D., Thieme, F., and Bonas, U. 2006. Type III effector proteins from the plant pathogen Xanthomonas and their role in the interaction with the host plant. J. Plant. Physiol. 163:233-255.

Guttman, D. S., Vinatzer, B. A., Sarkar, S. F., Ranall, M. V., Kettler, G., and Greenberg, J. T. 2002. A functional screen for the type III (Hrp) secretome of the plant pathogen Pseudomonas syringae. Science 295:1722-1726.

Hotson, A., Chosed, R., Shu, H., Orth, K., and Mudgett, M. B. 2003. Xanthomonas type III effector XopD targets SUMO-conjugated proteins in planta. Mol. Microbiol. 50:377-389.

Janjusevic, R., Abramovitch, R. B., Martin, G. B., and Stebbins, C. E. 2006. A bacterial inhibitor of host programmed cell death defenses is an E3 ubiquitin ligase. Science 311:222-226.

Jones, J. B., Lacy, G. H., Bouzar, H., Stall, R. E., and Schaad, N. W. 2004. Reclassification of the xanthomonads associated with bacterial spot disease of tomato and pepper. Syst. Appl. Microbiol. 27:755-762.

Karimi, M., Inze, D., and Depicker, A. 2002. GATEWAY vectors for Agrobacterium-mediated plant transformation. Trends Plant Sci. 7:193-195.

Katagiri, F., Thilmony, R., and He, S. Y. 2002. The Arabidopsis thalianaPseudomonas syringae interaction. Pages 1-35 in: The Arabidopsis Book. C. R. Somerville and E. M. Meyerowitz, eds. American Society of Plant Biologists, Rockville, MD, U.S.A.

Klement, Z. 1982. Hypersensitivity. Pages 149-177 in: Phytopathogenic Prokaryotes. M. S. Mount and G. H. Lacy, eds, Academic Press, New York

Knoop, V., Staskawicz, B., and Bonas, U. 1991. Expression of the avirulence gene avrBs3 from Xanthomonas campestris pv. vesicatoria is not under the control of hrp genes and is independent of plant factors. J. Bacteriol. 173:7142-7150.

Koebnik, R., Krüger, A., Thieme, F., Urban, A., and Bonas, U. 2006. Specific binding of the Xanthomonas campestris pv. vesicatoria AraC-type transcriptional activator $\mathrm{HrpX}$ to plant-inducible promoter boxes. J. Bacteriol. 188:7652-7660.

Lindeberg, M., Stavrinides, J., Chang, J. H., Alfano, J. R., Collmer, A., Dangl, J. L., Greenberg, J. T., Mansfield, J. W., and Guttman, D. S. 2005. Proposed guidelines for a unified nomenclature and phylogenetic analysis of type III Hop effector proteins in the plant pathogen Pseudomonas syringae. Mol. Plant-Microbe Interact. 18:275-282.

Linder, M. E., and Deschenes, R. J. 2007. Palmitoylation: Policing protein stability and traffic. Nat. Rev. Mol. Cell Biol. 8:74-84.

Makarova, K. S., Aravind, L., and Koonin, E. V. 1999. A superfamily of archaeal, bacterial, and eukaryotic proteins homologous to animal transglutaminases. Protein Sci. 8:1714-1719.

Maurer-Stroh, S., and Eisenhaber, F. 2004. Myristoylation of viral and bacterial proteins. Trends Microbiol. 12:178-185.

Minsavage, G. V., Dahlbeck, D., Whalen, M. C., Kearny, B., Bonas, U., Staskawicz, B. J., and Stall, R. E. 1990. Gene-for-gene relationships specifying disease resistance in Xanthomonas campestris pv. vesicatoria-pepper interactions. Mol. Plant-Microbe Interact. 3:41-47.

Mudgett, M. B. 2005. New insights to the function of phytopathogenic bacterial type III effectors in plants. Annu. Rev. Plant Biol. 56:509-531.

Mukherjee, S., Keitany, G., Li, Y., Wang, Y., Ball, H. L., Goldsmith, E. J., and Orth, K. 2006. Yersinia YopJ acetylates and inhibits kinase activation by blocking phosphorylation. Science 312:1211-1214.

Mulder, N. J., Apweiler, R., Attwood, T. K., Bairoch, A., Bateman, A., Binns, D., Bork, P., Buillard, V., Cerutti, L., Copley, R., Courcelle, E., Das, U., Daugherty, L., Dibley, M., Finn, R., Fleischmann, W., Gough, J., Haft, D., Hulo, N., Hunter, S., Kahn, D., Kanapin, A., Kejariwal, A., Labarga, A., Langendijk-Genevaux, P. S., Lonsdale, D., Lopez, R., Letunic, I., Madera, M., Maslen, J., McAnulla, C., McDowall, J., Mistry, J., Mitchell, A., Nikolskaya, A. N., Orchard, S., Orengo, C., Petryszak, R., Selengut, J. D., Sigrist, C. J.,Thomas, P. D., Valentin, F., Wilson, D., Wu, C. H., and Yeats, C. 2007. New developments in the InterPro database. Nucleic Acids Res. 35:D224-228.

Murillo, J., Shen, H., Gerhold, D., Sharma, A., Cooksey, D. A., and Keen, N. T. 1994. Characterization of pPT23B, the plasmid involved in syringolide production by Pseudomonas syringae pv. tomato PT23. Plasmid 31:275-287.

Nimchuk, Z., Marois, E., Kjemtrup, S., Leister, R. T., Katagiri, F., and Dangl, J. L. 2000. Eukaryotic fatty acylation drives plasma membrane targeting and enhances function of several type III effector proteins from Pseudomonas syringae. Cell 101:353-363.

Nimchuk, Z. L., Fisher, E. J., Desvaux, D., Chang, J. H., and Dangl, J. L. 2007. The HopX (AvrPphE) family of Pseudomonas syringae type III effectors require a catalytic triad and a novel $\mathrm{N}$-terminal domain for function. Mol. Plant-Microbe Interact. 20:346-357.
Noël, L., Thieme, F., Nennstiel, D., and Bonas, U. 2001. cDNA-AFLP analysis unravels a genome-wide $h r p G$-regulon in the plant pathogen Xanthomonas campestris pv. vesicatoria. Mol. Microbiol. 41:1271-1281.

Noël, L., Thieme, F., Nennstiel, D., and Bonas, U. 2002. Two novel type III-secreted proteins of Xanthomonas campestris pv. vesicatoria are encoded within the hrp pathogenicity island. J. Bacteriol. 184:1340-1348.

Noël, L., Thieme, F., Gäbler, J., Büttner, D., and Bonas, U. 2003. XopC and XopJ, two novel type III effector proteins from Xanthomonas campestris pv. vesicatoria. J. Bacteriol. 185:7092-7102.

Nürnberger, T., Brunner, F., Kemmerling, B., and Piater, L. 2004. Innate immunity in plants and animals: Striking similarities and obvious differences. Immunol. Rev. 198:249-266.

Orth, K., Xu, Z., Mudgett, M. B., Bao, Z. Q., Palmer, L. E., Bliska, J. B., Mangel, W. F., Staskawicz, B., and Dixon, J. E. 2000. Disruption of signaling by Yersinia effector YopJ, ubiquitin-like protein protease. Science 290:1594-1597.

Rawlings, N. D., Morton, F. R., and Barrett, A. J. 2006. MEROPS: The peptidase database. Nucleic Acids Res. 34:D270-272.

Robert-Seilaniantz, A., Shan, L., Zhou, J.-M., and Tang, X. 2006. The Pseudomonas syringae pv. tomato DC3000 type III effector HopF2 has a putative myristoylation site required for its avirulence and virulence functions. Mol. Plant-Microbe Interact. 19:130-138.

Roden, J., Eardley, L., Hotson, A., Cao, Y., and Mudgett, M. B. 2004a. Characterization of the Xanthomonas AvrXv4 effector, a SUMO protease translocated into plant cells. Mol. Plant-Microbe Interact. 17:633643.

Roden, J. A., Belt, B., Ross, J. B., Tachibana, T., Vargas, J., and Mudgett, M. B. 2004b. A genetic screen to isolate type III effectors translocated into pepper cells during Xanthomonas infection. Proc. Natl. Acad. Sci. U.S.A. 101:16624-16629.

Rohmer, L., Guttman, D.S., and Dangl, J. L. 2004. Diverse evolutionary mechanisms shape the type III effector virulence factor repertoire in the plant pathogen Pseudomonas syringae. Genetics 167:1341-1360.

Rossier, O., Van den Ackerveken, G., and Bonas, U. 2000. HrpB2 and HrpF from Xanthomonas are type III-secreted proteins and essential for pathogenicity and recognition by the host plant. Mol. Microbiol. 38:828-838.

Rossier, O., Wengelnik, K., Hahn, K., and Bonas, U. 1999. The Xanthomonas Hrp type III system secretes proteins from plant and mammalian pathogens. Proc. Natl. Acad. Sci. U.S.A. 96:9368-9373.

Schäfer, A., Tauch, A., Jäger, W., Kalinowski, J., Thierbach, G., and Pühler, A. 1994. Small mobilizable multi-purpose cloning vectors derived from the Escherichia coli plasmids pK18 and pK19: Selection of defined deletions in the chromosome of Corynebacterium glutamicum. Gene 145:69-73.

Schechter, L. M., Vencato, M., Jordan, K. L., Schneider, S. E., Schneider, D. J., and Collmer, A. 2006. Multiple approaches to a complete inventory of Pseudomonas syringae pv. tomato DC3000 type III secretion system effector proteins. Mol. Plant-Microbe Interact. 19:1180-1192.

Schornack, S., Meyer, A., Romer, P., Jordan, T., and Lahaye, T. 2006. Gene-for-gene-mediated recognition of nuclear-targeted AvrBs3-like bacterial effector proteins. J. Plant Physiol. 163:256-272.

Schulte, R., and Bonas, U. 1992. Expression of the Xanthomonas campestris pv. vesicatoria hrp gene cluster, which determines pathogenicity and hypersensitivity on pepper and tomato, is plant inducible. J. Bacteriol. 174:815-823.

Shan, L., Thara, V. K., Martin, G. B., Zhou, J.-M., and Tang, X. 2000. The Pseudomonas AvrPto protein is differentially recognized by tomato and tobacco and is localized to the plant plasma membrane. Plant Cell 12:2323-2337.

Staskawicz, B. J. 2001. Genetics of plant-pathogen interactions specifying plant disease resistance. Plant Physiol. 125:73-76.

Stavrinides, J., Ma, W., and Guttman, D. S. 2006. Terminal reassortment drives the quantum evolution of type III effectors in bacterial pathogens. PLoS Pathog. 2:e104.

Szurek, B., Rossier, O., Hause, G., and Bonas, U. 2002. Type III-dependent translocation of the Xanthomonas AvrBs3 protein into the plant cell. Mol. Microbiol. 46:13-23.

Thieme, F., Koebnik, R., Bekel, T., Berger, C., Boch, J. Büttner, D., Caldana, C., Gaigalat, L., Goesmann, A., Kay, S., Kirchner, O., Lanz, C., Linke, B., McHardy, A. C., Meyer, F., Mittenhuber, G., Nies, D. H., Niesbach-Klösgen, U., Patschkowski, T., Rückert, C., Rupp, O., Schneiker, S., Schuster, S. C., Vorhölter, F., Weber, E., Pühler, A., Bonas, U., Bartels, D., and Kaiser, O. 2005. Insights into genome plasticity and pathogenicity of the plant pathogenic bacterium Xanthomonas campestris pv. vesicatoria revealed by the complete genome sequence. J. Bacteriol. 187:7254-7266.

Van den Ackerveken, G., Marois, E., and Bonas, U. 1996. Recognition of the bacterial avirulence protein AvrBs3 occurs inside the host plant cell. Cell 87:1307-1316. 
Van Larebeke, N., Engler, G., Holsters, M., Van den Elsacker, S., Zaenen, I., Schilperoort, R. A., and Schell, J. 1974. Large plasmid in Agrobacterium tumefaciens essential for crown gall-inducing ability. Nature 252:169-170

Vauterin, L., Rademaker, J., and Swings, J. 2000. Synopsis on the taxonomy of the genus Xanthomonas. Phytopathol. 90:677-682.

Wengelnik, K., and Bonas, U. 1996. HrpXv, an AraC-type regulator, activates expression of five of the six loci in the hrp cluster of Xanthomonas campestris pv. vesicatoria. J. Bacteriol. 178:3462-3469.

Wengelnik, K., Van den Ackerveken, G., and Bonas, U. 1996. HrpG, a key hrp regulatory protein of Xanthomonas campestris pv. vesicatoria is homologous to two-component response regulators. Mol. Plant-Microbe
Interact. 9:704-712.

Wengelnik, K., Rossier, O., and Bonas, U. 1999. Mutations in the regulatory gene hrpG of Xanthomonas campestris pv. vesicatoria result in constitutive expression of all hrp genes. J. Bacteriol. 181:6828-6831.

Ye, J., McGinnis, S., and Madden, T. L. 2006. BLAST: Improvements for better sequence analysis. Nucleic Acids Res. 34:W6-9.

Zacharias, D. A., Violin, J. D., Newton, A. C., and Tsien, R. Y. 2002. Partitioning of lipid-modified monomeric GFPs into membrane microdomains of live cells. Science 296:913-916.

Zhu, H. Q., Hu, G. Q., Ouyang, Z. Q., Wang, J., and She, Z. S. 2004. Accuracy improvement for identifying translation initiation sites in microbial genomes. Bioinformatics 20:3308-3317.

This article was modified on January 9, 2018. 
ERRATUM / Volume 20, Number 10, 2007 / MPMI-20-10-1250

In the article "New Type III Effectors from Xanthomonas campestris pv. Vesicatoria Trigger Plant Reactions Dependent on a Conserved N-Myristoylation Motif" by F. Thieme, R. Szczesny, A. Urban, O. Kirchner, G. Hause, and U. Bonas, Caption text has been added to reflect that Figure 3B shows a magnification of the nucleus- and chloroplast-containing areas from Figure 3A but, for XopE1-GFP, the magnified area does not correspond to the area shown in Figure 3A.

\section{Revised text for Figure 3B}

B, Magnifications of nucleus- and chloroplast-containing areas from the merged view in A, respectively. White arrows indicate cytoplasmic strands that span through the tonoplast. The size bars correspond to $20 \mu \mathrm{m}$. Note that, for XopE1::GFP, a different section from the same experiment is shown.

\section{Previously Published version}

B, Magnifications of nucleus- and chloroplast-containing areas from the merged view in A, respectively. White arrows indicate cytoplasmic strands that span through the tonoplast. The size bars correspond to $20 \mu \mathrm{m}$. 